\title{
GEOLOGICAL SURVEY OF CANADA RADIOCARBON DATES IX
}

\author{
J. A. LOWDON and W. BLAKE, JR.* \\ Geological Survey of Canada, Ottawa, Canada
}

\section{INTRODUCTION}

Both the 2-L counter, described in GSC I (Radiocarbon, 1962, v. 4, p. 13-26), and the 5-L counter (GSC IV, Radiocarbon, 1965, v. 7, p. 24-46) were operated routinely during the past year. Approximately half the determinations reported were obtained from each counter. The 2-L counter was operated at 2 atm except for August and September, 1968, when it was operated for the first time at $1 \mathrm{~atm}$. This allowed for the counting of most small samples without the necessity of mixing with dead gas. The 5-L counter was operated at 1 atm, except for the same period when it was operated at 4 atm. Carbon dioxide is used as the counting gas, and both counters are of the proportional type.

All age calculations are carried out monthly by a C.D.C. $3100 \mathrm{com}$ puter and are based on a $\mathrm{C}^{14}$ half-life of $5568 \pm 30 \mathrm{yr}$ and 0.95 of the activity of the NBS oxalic-acid standard. Ages are quoted in years before 1950. Age errors include: counting errors of sample, background, and standard; error in the half-life of $\mathrm{C}^{14}$; and an error term to account for the average variation of $\pm 1.5 \%$ in the $\mathrm{C}^{14}$ concentration of the biosphere during the past $1100 \mathrm{yr}$. The error assigned to an age is always a minimum of $\pm 100 \mathrm{yr}$. Finite ages are based on the $2 \sigma$ criterion and "Infinite" ages on the $4 \sigma$ criterion (Radiocarbon, 1962, v. 4, p. 13-26). Unless otherwise stated in the sample descriptions all ages are based on two 1-day counts.

One change has been made in the purification technique described in GSC VIII (Radiocarbon, 1969, v. 11, p. 22-42). The hot (400 $\mathrm{C}$ ) Pt. asbestos - $\mathrm{Ag}$ wool furnace was removed from the purification line in order to test its effect on the purity of the $\mathrm{CO}_{2}$ gas. Since there was no detectable change in the gas purity this furnace was not re-installed in the purification line.

Average background and standard counting rates over the past 12 months are listed in Tables 1 and 2 respectively.

With respect to the 2 - $\mathrm{L}$ counter operating at $1 \mathrm{~atm}$, the August background is the average of 4 individual daily counts. One background result was omitted for statistical reasons. The September background is the average of 6 individual daily counts. For this 2 month period, 5 different background preparations were counted. At an operating pressure of $2 \mathrm{~atm}$, the 2-L monthly backgrounds are the average of 4 individual daily counts. From a total of 42 background determinations (October 1967 to July 1968 inclusive) 2 were omitted for statistical reasons. During this 10 -month period, 11 different background preparations were used.

* The introductory part of this paper has been prepared by the first author, who operates the laboratory. The date list has been compiled by the second author from descriptions of samples and interpretations of dates by the collectors. 
TABLE 1

Monthly Background (c/m) for Period, Oct. 1, 1967 to Sept. 30, 1968

\begin{tabular}{llc} 
Month & $\begin{array}{c}\text { 2-L counter } \\
(2 \mathrm{~atm})\end{array}$ & $\begin{array}{c}5 \text {-L counter } \\
(1 \mathrm{~atm})\end{array}$ \\
\hline October 1967 & $1.188 \pm .036$ & $2.122 \pm .032$ \\
November & $1.220 \pm .020$ & $2.122 \pm .038$ \\
December & $1.200 \pm .023$ & $2.157 \pm .043$ \\
January 1968 & $1.180 \pm .024$ & $2.154 \pm .027$ \\
February & $1.184 \pm .024$ & $2.176 \pm .024$ \\
March & $1.162 \pm .019$ & $2.177 \pm .039$ \\
April & $1.182 \pm .036$ & $2.162 \pm .044$ \\
May & $1.154 \pm .031$ & $2.061 \pm .032$ \\
June & $1.131 \pm .019$ & $2.099 \pm .026$ \\
July & $1.121 \pm .018$ & $2.115 \pm .022$ \\
August & $1.012 \pm .016^{*}$ & $?$ \\
September & $1.079 \pm .016^{*}$ & $2.775 \pm .021 * *$ \\
\hline * & &
\end{tabular}

* 2-L counter operating at 1 atm.

** 5-L counter operating at $4 \mathrm{~atm}$.

The 5-L counter was operated at 4 atm during August and September. The background for this 2 month period is the average of 12 individual daily counts. No background results had to be omitted, and 4 different preparations were used. At $1 \mathrm{~atm}$, the 5-L counter monthly backgrounds are the average of 4 individual daily counts. None were omitted, and 9 different background preparations were used.

\section{TABLE 2}

Monthly Standard, No*, (c/m) for Period, Oct. 1, 1967 to Sept. 30, 1968

\begin{tabular}{lcc}
\hline \multicolumn{1}{c}{ Month } & $\begin{array}{c}\text { 2-L counter } \\
(2 \mathrm{~atm})\end{array}$ & $\begin{array}{c}\text { 5-L counter } \\
(\mathrm{l} \mathrm{atm})\end{array}$ \\
\hline October 1967 & $19.984 \pm .109$ & $29.153 \pm .129$ \\
November & $19.943 \pm .097$ & $28.877 \pm .121$ \\
December & $20.130 \pm .158$ & $28.925 \pm .127$ \\
January 1968 & $19.999 \pm .097$ & $28.953 \pm .097$ \\
February & $20.103 \pm .196$ & $28.747 \pm .122$ \\
March & $19.977 \pm .119$ & $28.704 \pm .123$ \\
April & $19.895 \pm .106$ & $29.035 \pm .124$ \\
May & $20.006 \pm .099$ & $28.767 \pm .192$ \\
June & $20.071 \pm .083$ & $29.136 \pm .114$ \\
July & $19.980 \pm .094$ & $28.955 \pm .114$ \\
August & $9.732 \pm .056^{* *}$ & ? $111.719 \pm .158 \dagger$ \\
September & $9.668 \pm .096 * *$ & \\
\hline
\end{tabular}

${ }^{*} \mathrm{~N}_{\mathrm{o}}=0.95 \times$ net counting rate of the NBS oxalic-acid standard.

** 2-L counter operating at 1 atm.

$\dagger 5$ - $\mathrm{L}$ counter operating at 4 atm. 
For the 2-L counter operating at 1 atm, the August and September average monthly standard counting rates are each the average of 4 daily counts. No counts were omitted. All 8 counts were carried out using the same oxalic-acid preparation. The monthly standards at 2 atm are the averages of 3 individual daily counts. No counts were omitted, and 6 different oxalic-acid preparations were used.

At $4 \mathrm{~atm}$, the 5-L standard counting rate is made up of the average of 6 individual daily counts. No counts were omitted and the same oxalic-acid preparation was used for all determinations. At 1 atm the 5-L standard counting rates consist of the monthly average of 3 individual daily counts. Seven oxalic-acid preparations were used, and 1 result was omitted for statistical reasons.

A comparison of ages obtained on the same sample at different counter pressures is shown in Table 3. All determinations were carried out in the 5-L counter and all samples were given the same acid and base pretreatment, except for GSC-993 and GSC-1002 where the base treatment was omitted.

TABLE 3*

Comparison of ages at different pressures in 5-L counter

\begin{tabular}{lccc}
\hline Sample no. & $\begin{array}{c}\text { Length of count } \\
\text { (days) }\end{array}$ & $\begin{array}{c}\text { Pressure } \\
\text { (atm) }\end{array}$ & $\begin{array}{c}\text { Age } \\
\text { (yr. B.P.) }\end{array}$ \\
\hline GSC-629** & 3 & 1 & $>41,000$ \\
GSC-629-2 & 5 & 4 & $40,200 \pm 480$ \\
GSC-993 & 3 & 1 & $>37,000$ \\
GSC-993-2 & 4 & 4 & $46,400 \pm 940$ \\
GSC-1002 & 1 & 1 & $>40,000$ \\
GSC-1002-2 & 5 & 4 & $>48,000$ \\
GSC-1019 & 2 & 1 & $>40,000$ \\
GSC-1019-2 & 5 & 4 & $52,200 \pm 1760$
\end{tabular}
date list.

* Detailed descriptions of samples GSC-629, 993, and 1019 are deferred to a later

** GSC-629 was prepared from wood only whereas GSC-629-2 was prepared from wood plus plant detritus. Presence of material younger than the wood could account for the fact that the high pressure age appears younger than the low pressure age.

Table 4 illustrates the effects of different pretreatment methods on bone samples. The samples were originally treated with dilute $\mathrm{HCl}$ to remove carbonates (Radiocarbon, 1969, v. 11, p. 22-42). From the results obtained it would appear that the amount of base treatment does not affect significantly the final ages obtained for these samples from an Arctic environment.* However, contamination of bones by soil organics can occur (Berger and Libby, 1966), and, therefore, some amount of base treatment is essential.

* These 3 samples were coll. near Cape Storm, Ellesmere I. All 3 bones were imbedded in sand and gravel of raised beaches; they have been subjected to freezing for much of the year, and to intermittent wetting during the summer. 
TABLE 4

Tests on bone contamination by varying pretreatment*

\begin{tabular}{lcccc}
\hline & $\begin{array}{c}\text { Base } \\
\text { treatment } \\
\text { Sample no. }\end{array}$ & $\begin{array}{c}\text { Uncorrected } \\
\text { age } \\
\text { (0.1 N NaOH })\end{array}$ & $\begin{array}{c}\text { Corrected } \\
\text { age }\end{array}$ \\
\hline GSC-979 & none & $5460 \pm 140$ & -16.1 & $5600 \pm 140$ \\
GSC-979-2 & 1 hour & $5270 \pm 140$ & & \\
GSC-980 & none & $830 \pm 140$ & -15.8 & $980 \pm 140$ \\
GSC-980-2 & 1 hour & $930 \pm 140$ & -23.7 & $940 \pm 140$ \\
GSC-1021 & $\approx 24$ hours & $4360 \pm 140$ & -16.3 & $4490 \pm 140$ \\
GSC-1021-2 & 1 hour & $4440 \pm 140$ & -15.9 & $4580 \pm 140$ \\
\hline
\end{tabular}

* Detailed descriptions of these samples are deferred to a later date list.

Table 5 illustrates further results obtained from different fractions of the same sample or of related samples.

TABLE $5 *$

Tests for $\mathrm{C}^{14}$ Contamination

\begin{tabular}{|c|c|c|}
\hline Sample no. & Fraction & $\begin{array}{c}\text { Age } \\
\text { (yr B.P.) }\end{array}$ \\
\hline \multicolumn{3}{|c|}{ A. Marl and Organic Detritus } \\
\hline \multirow[t]{2}{*}{ GSC-657 } & Inorganic (marl) & $13,200 \pm 170$ \\
\hline & Organic & $13,800 \pm 170$ \\
\hline GSC-662 & Gyttja (immediately below GSC-657) & $11,200 \pm 200$ \\
\hline \multirow[t]{2}{*}{ GSC-675 } & Inorganic (marl) & $12,100 \pm 170$ \\
\hline & Organic & $11,500 \pm 180$ \\
\hline \multirow[t]{2}{*}{ GSC-875 } & Inorganic (marl) & $8540 \pm 140$ \\
\hline & Organic & $8310 \pm 150$ \\
\hline GSC-1027 & Inorganic (marl, 253-259 cm depth) & $33,900 \pm 1250$ \\
\hline GSC-1023 & $\begin{array}{l}\text { Organic (left after marl at } 289-295 \\
\mathrm{~cm} \text { depth treated with } \mathrm{H}_{3} \mathrm{PO}_{4} \text { ) }\end{array}$ & $11,500 \pm 160$ \\
\hline \multicolumn{3}{|l|}{ B. Peat } \\
\hline \multirow[t]{2}{*}{ GSC-879 } & less soluble** & $4700 \pm 130$ \\
\hline & more soluble & $4830 \pm 160$ \\
\hline
\end{tabular}

* Detailed descriptions of all samples appear in this date list except for GSC-879, 1023 , and 1027 , deferred to a later list.

** Degree of solubility refers to solubility in $2 \% \mathrm{NaOH}$.

From the results obtained so far (cf. also Radiocarbon: 1963, v. 5, p. $39-55$; 1965 , v. 7 , p. $24-46$; 1968 , v. 10 , p. 207-245) it is not possible to generalize regarding the validity of marl dates. The data listed in Table 
5 show that the age of marl can be younger than, similar to, or older than that of the included organic material. In two localities the dates on gyttja below the marl samples give an indication of how much in error dates on both marl and included organic material can be (cf. GSC-657 and GSC-662, New Brunswick; GSC-1023 and GSC-1027, Ontario). Further investigation of this problem is planned.

All samples with an age of less than $5000 \mathrm{yr}$ are now being submitted to Isotopes, Inc. for $\mathrm{C}^{13} / \mathrm{C}^{12}$ determinations in order to evaluate, and correct for, effects of carbon isotope fractionation. The $5000 \mathrm{yr}$ cut-off point is purely arbitrary and may be revised in the future. The results obtained so far have shown that all bone and soil samples are subject to fractionation, as well as many peat samples and some wood samples. Corrections ranged as follows: bones $(+20$ to $+150 \mathrm{yr})$; soils $(-30$ to $+100 \mathrm{yr})$; peats $(-40$ to $+110 \mathrm{yr})$; $\operatorname{wood}(-80$ to $+70 \mathrm{yr})$; charcoal $(0$ to $+20 \mathrm{yr}$ ). In the future $\mathrm{C}^{13} / \mathrm{C}^{12}$ determinations will be carried out on all bone and soil samples, regardless of age. In this date list, where $\delta \mathrm{C}^{13}$ measurements are available, a correction for isotopic fractionation has been applied to each date, and the $\delta \mathrm{C}^{13}$ value reported. Related to the PDB standard, normal values are taken to be $-25.0 \%$ for wood, other terrestrial organic material, and bones (terrestrial and marine) and $0.0 \%$ for marine shells.

\section{ACKNOWLEDGMENTS}

Thanks are extended to Ian M. Robertson, Suzanne Lafleur, and David Hodgkin for assistance in the preparation and measurement of samples in the laboratory, and to Gretchen Minning for assistance in compilation of the date list.

\section{SAMPLE DESCRIPTIONS}

I. GEOLOGIC SAMPLES

\section{A. Eastern Cianada}

\section{GSC-868. Cox's Cove, Newfoundland}

$12,600 \pm 170$

10,650 B.C.

Marine shells and shell fragments (mostly Hiatella arctica, Mya truncata, Serripes groenlandicus, and Macoma calcarea) from gray and red silty clay at alt 120 to $130 \mathrm{ft}$ in roadcut ca. $0.5 \mathrm{mi} \mathrm{SW}$ of town of Cox's Cove, Middle Arm, Newfoundland $\left(49^{\circ} 07^{\prime} \mathrm{N}\right.$ Lat, $58^{\circ} 05^{\prime} \mathrm{W}$ Long). Shell-bearing clay overlain by ca. 5 to $10 \mathrm{ft}$ red clay and $3 \mathrm{ft}$ sand which grades shoreward into cobble gravel to marine limit at ca. 165 ft. Coll. 1967 by V. K. Prest.* Comment (V.K.P.): date believed to refer to sea level close to marine limit established following retreat of Newfoundland Ice Cap from W coastal area (Brookes, 1969). Marine limit corresponds closely with that determined by Flint (1940) at Cornerbrook, $12 \mathrm{mi} \mathrm{SE}$.

* All persons referred to as collectors or submitters of samples or otherwise cited as sources of data are with the Geological Survey of Canada unless otherwise specified. 
GSC-937. Rocky Point, Port au Port Bay,

$13,200 \pm 220$ Newfoundland

11,250 в. C.

$\delta C^{13}=+1.9 \%$

Fragments of marine shells (mainly Mya arenaria) from exposure ca. 200 yds $\mathrm{N}$ of Rocky Pt., W side of Port au Port Bay, Newfoundland ( $48^{\circ} 39.1^{\prime} \mathrm{N}$ Lat, $58^{\circ} 57.4 \mathrm{~W}$ Long); $12 \mathrm{ft}$ above present beach in marine clay (ca. $6 \mathrm{ft}$ thick band overlies bedrock) with abundant interspersed boulders (ice rafted). Coll. 1966 by J. M. Shearer, Memorial Univ., St. John's; now at Dalhousie Univ., Halifax. Comment (J.M.S.): date is probably close to time of deglaciation of area (Brookes, 1969). Sample mixed with dead gas for counting. Date based on one 3-day count.

GSC-887. Gilbert Cove, Nova Scotia

Marine shells (Mercenaria mercenaria, id. by A. H. Clarke, Jr., Natl. Mus. of Canada, Ottawa) from trench cut in gray clay beneath sand and gravel, $200 \mathrm{yds}$ inland from present shore of Gilbert Cove, St. Mary's Bay, Nova Scotia $\left(44^{\circ} 29^{\prime} 10^{\prime \prime} \mathrm{N}\right.$ Lat, $65^{\circ} 57^{\prime} 10^{\prime \prime} \mathrm{W}$ Long) at alt ca. $45 \mathrm{ft}$. Shelly clay was covered by sand and gravel before excavation. Coll. 1967 by J. Welsted, Brandon Univ., Brandon, Manitoba. Comment (J.W.): date provides evidence that at one stage, over 39,000 yr ago, SW Nova Scotia coast stood ca. $50 \mathrm{ft}$ lower, relative to sea level, than at present. A similar date, $>38,000$ (GSC-695; Radiocarbon, 1968, v. 10, p. 211), was obtained on shells coll. by D. R. Grant from stony clay near Cape St. Mary, ca. $30 \mathrm{mi} \mathrm{S}$ of Gilbert Cove along W coast of Nova Scotia. Two fractions were dated after removal of outer $20 \%$ of shell:

$$
\begin{array}{ll}
\text { outer fraction, }(21-60 \% \text { leach) two 1-day counts } & >38,000 \\
\text { inner fraction, (61-100\% leach) one 3-day count } & >39,000
\end{array}
$$

\section{Recent submergence series, Nova Scotia and New Brunswick}

The following 17 dates, part of a series, deal with recent submergence in Nova Scotia and New Brunswick. Materials dated are freshwater peat, sedge (brackish water) peat, salt marsh peat, stumps from submerged forests, and marine shells. Coll. 1966, 1967, 1968 by D. R. Grant at widely separated localities to trace history of relative sea level movements. Samples are from natural intertidal exposures unless otherwise noted. Elevations are referred to higher high water spring tides.

\section{GSC-910. Great Tancook Island, Nova Scotia}

$$
\begin{aligned}
& 1040 \pm 130 \\
& \text { A.D. } 910 \\
& \delta C^{13}=-25.4 \% 。
\end{aligned}
$$

Stump rooted in till at $-6.0 \mathrm{ft}$, overlain by sedge peat grading onto salt marsh peat, at head of Southeast Cove, Great Tancook I. $\left(44^{\circ} 26.9^{\prime}\right.$ $\mathrm{N}$ Lat, $64^{\circ} 10.3^{\prime}$ W Long).

\section{GSC-731. Hawk Point, Nova Scotia, peat}

$1470 \pm 130$

Freshwater peat from extensive submerged bog at Hawk Point, 1 mi S of Lower Clark's Harbour, Cape Sable I. $\left(43^{\circ} 25.0^{\prime} \mathrm{N}\right.$ Lat, $65^{\circ} 36.8^{\prime}$ 
$\mathrm{W}$ Long). Grab sample taken underwater at $-20 \mathrm{ft}$, ca. $4 \mathrm{ft}$ below waveplaned bog surface.

\section{GSC-899. Hawk Point, Nova Scotia, wood}

$$
\begin{array}{r}
1230 \\
\text { A.D. } 720
\end{array}
$$$$
\delta C^{13}=-24.0 \%
$$

Stump at $-11.0 \mathrm{ft}$, rooted in till, at Hawk Point, $1 \mathrm{mi} \mathrm{S}$ of Lower Clark's Harbour Cape Sable I. (43 $24.8^{\prime}$ N Lat, $65^{\circ} 36.9^{\prime}$ W Long). Stump from forest zone assoc. with peat dated as GSC-731 and at same level as salt marsh peat outcropping on beach slope.

\section{GSC-918. Double Island, Nova Scotia}

$$
\begin{aligned}
& 1010 \pm 130 \\
& \text { A.D. } 940 \\
& \delta C^{13}=-23.4 \%
\end{aligned}
$$

Stump rooted in thin humus over till at $-5.5 \mathrm{ft}$, overlain by few in. sedge peat buried by high tide salt marsh peat; $\mathrm{E}$ side of tombolo on Double I. in Pubnico Harbour ( $43^{\circ} 40.1^{\prime} \mathrm{N}$ Lat, $65^{\circ} 47.5^{\prime} \mathrm{W}$ Long).

\section{GSC-1046. Chebogue Point, Nova Scotia \\ $3330 \pm 140$ \\ 1380 B.c. \\ $\delta C^{13}=-18.1 \%$}

Sedge peat from bore hole through salt marsh sediment; 19.7 to 21.3 $\mathrm{ft}$ below marsh surface and $-3.9 \mathrm{ft}$ below datum; $0.3 \mathrm{mi}$ NNE of Chebogue Point, Nova Scotia (43 $44.4^{\prime}$ N Lat, $66^{\circ} 07.0^{\prime} \mathrm{W}$ Long).

\section{GSC-900. Church Point, Nova Scotia}

$5060 \pm 130$

Stump rooted in till at $-12.0 \mathrm{ft}$ at Church Point, $0.2 \mathrm{mi} \mathrm{N}$ of light-

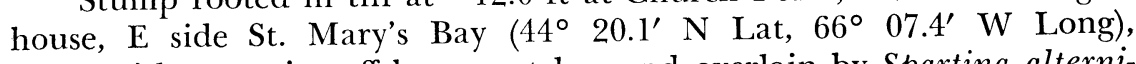
assoc. with extensive offshore peat bog and overlain by Spartina alterniflora peat.

\section{GSC-1052. Brighton, Nova Scotia}

$$
\begin{aligned}
& \quad 1320 \pm 130 \\
& \text { A.p. } 630 \\
& \delta C^{13}=-21.4 \%
\end{aligned}
$$

Corms of Scirpus sp., intermediate between freshwater peat below and salt marsh above, $-10.0 \mathrm{ft}$ below datum; $0.3 \mathrm{mi}$ WSW of Brighton, Nova Scotia (44ㅇ․ $32.9^{\prime} \mathrm{N}$ Lat, $65^{\circ} 51.9^{\prime} \mathrm{W}$ Long).

$\begin{array}{ll}\text { GSC-997. Head of St. Mary's Bay, } & \mathbf{7 6 0} \pm 130 \\ \text { Nova Scotia } & \text { A.D. } 1190 \\ \delta C^{13}=-22.6 \%\end{array}$

Rhizomes of Scirpus sp. at $-8.0 \mathrm{ft}$; from top of 3 in. sedge peat over till, under $6 \mathrm{ft}$ high tide salt marsh peat, $5 \mathrm{mi}$ SW of Digby at head of St. Mary's Bay ( $44^{\circ} 34.77^{\prime} \mathrm{N}$ Lat, $65^{\circ} 51.4^{\prime} \mathrm{W}$ Long).

\section{GSC-972. Grand Pré, Nova Scotia, -29 ft}

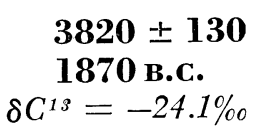

Stump at $-29 \mathrm{ft}$, rooted in till, exposed by erosion of formerly overlying salt marsh wedge. Site is opposite Boot I., $2 \mathrm{mi} \mathrm{NE}$ of Grand Pré, Minas Basin ( $45^{\circ} 08.25^{\prime}$ N Lat, $64^{\circ} 17.14^{\prime} \mathrm{W}$ Long). 
GSC-1054. Grand Pré, Nova Scotia, -27 ft

Stump at $-27.0 \mathrm{ft}$, rooted in till, exposed by erosion of formerly overlying salt marsh. Location as above.

GSC-757. Saint's Rest, Nova Scotia, wood

$8180 \pm 150$

ing few in. of humus on till, and overlain by salt marsh peat; near lighthouse at Saint's Rest, mouth of Bass R., Cobequid Bay, Minas Basin (45 $23.9^{\prime}$ N Lat, $63^{\circ} 47.9^{\prime}$ W Long).

\section{GSC-922. Saint's Rest, Nova Scotia, salt marsh peat \\ $1260 \pm 140$ A.D. 690}

$\delta C^{1 s}=-20.5 \%$

Basal Spartina patens salt marsh peat at $-9.8 \mathrm{ft}$ overlying $26 \mathrm{ft}$ freshwater peat and stumps. Location as above.

$$
\begin{array}{rr}
\text { GSC-957. Highland Village, Nova Scotia, }-17 \text { ft } \begin{array}{r}
2070 \pm 130 \\
120 \text { B.c. }
\end{array} \delta C^{13}=-25.4 \%
\end{array}
$$

Stump at $-17.0 \mathrm{ft}$, rooted in till and overlain by few in. freshwater peat at Highland Village school, Cobequid Bay, Minas Basin $\left(45^{\circ} 23.5^{\prime}\right.$ $\mathrm{N}$ Lat, $63^{\circ} 39.00^{\prime} \mathrm{W}$ Long). Stumps exposed by erosion of overlying salt marsh wedge.

$$
\begin{array}{llr}
\text { GSC-1045. Highland Village, } & \mathbf{1 7 5 0} \pm 130 \\
\text { Nova Scotia, }-12 \text { ft } & \text { A.D. } 200 \\
\delta C^{13}=-26.8 \%
\end{array}
$$

Stump at $-12.0 \mathrm{ft}$, rooted in till and overlain by sedge (brackish water) peat and salt marsh peat. Location as above.

\section{GSC-973. Lyon Head, Nova Scotia}

$$
\begin{aligned}
& 1210 \pm 140 \\
& \text { A.D. } 740 \\
& \delta C^{13}=-25.0 \%
\end{aligned}
$$

Stumps at $-6.0 \mathrm{ft}$, rooted in till and overlain by salt marsh peat at Lyon Head, $5 \mathrm{mi} \mathrm{W}$ of Truro, on $\mathrm{N}$ side Cobequid Bay, Minas Basin ( $45^{\circ} 21.8^{\prime} \mathrm{N}$ Lat, $63^{\circ} 24.2^{\prime} \mathrm{W}$ Long).

\section{GSC-1032. Amherst Marsh, Nova Scotia}

$$
\begin{aligned}
& \quad \mathbf{9 8 0} \pm 140 \\
& \text { A.p. 970 } \\
& \delta C^{13}=-26.4 \%
\end{aligned}
$$

Sedge peat and humus over till at $-10.6 \mathrm{ft}$, from borehole 190 to 200 $\mathrm{cm}$ below surface of salt marsh $2 \mathrm{mi} \mathrm{W}$ of Amherst, Cumberland Basin, Bay of Fundy (45 $49.15^{\prime} \mathrm{N}$ Lat, $64^{\circ} 15.00^{\prime} \mathrm{W}$ Long).

$$
\begin{array}{lll}
\text { GSC-930. } & \text { Fort Beauséjour, } & \mathbf{4 0 4 0} \pm 130 \\
& \text { New Brunswick, }-39 \text { ft } & 2090 \text { B.c. } \\
& & \delta C^{13}=-23.1 \% 0
\end{array}
$$

Stump at $-39 \mathrm{ft}$ from submerged forest covering several acres on till surface underlying $36 \mathrm{ft}$ of high tide salt marsh sediment, $1 \mathrm{mi} \mathrm{SW}$ of 
fort on NE shore of Cumberland Basin, Bay of Fundy $\left(45^{\circ} 51.1^{\prime} \mathrm{N}\right.$ Lat, $64^{\circ} 18.1^{\prime}$ W Long).

GSC-975. Fort Beauséjour,

New Brunswick, -31 ft

\author{
$3520 \pm 140$ \\ 1570 B.c. \\ $\delta C^{13}=-25.4 \%$
}

Stump at $-31 \mathrm{ft}$, rooted in till and overlain, successively, by sedge peat and 28-ft-high tide salt marsh sediment. Location as bove.

GSC-1030. Fort Beauséjour,

New Brunswick, $-20.3 \mathrm{ft}$

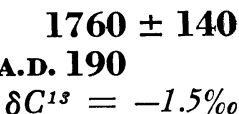

Shells (Mya arenaria) intact and in growth position at $-20.3 \mathrm{ft}(17.3$ $\mathrm{ft}$ below marsh surface, midway between top and bottom of sec. of salt marsh peat nearly $40 \mathrm{ft}$ thick). Location as above.

GSC-967. Cape Spear, New Brunswick

$$
\begin{array}{r}
930 \pm 130 \\
\text { A.D. } 1020 \\
\delta C^{13}=-25.1 \% \text { o }
\end{array}
$$

Stump at $-4.0 \mathrm{ft}$, rooted in till, overlain by few in. of sedge peat grading into salt marsh peat, $0.5 \mathrm{mi} \mathrm{NE}$ of Cape Spear on $\mathrm{N}$ shore Baie Verte, Northumberland Strait (46 $46^{\circ} 05.42^{\prime} \mathrm{N}$ Lat, $63^{\circ} 47.80^{\prime} \mathrm{W}$ Long). General Comment (D.R.G.): except for GSC-731 which has been displaced by compaction, and for GSC-757 and GSC-900 which show age anomalies due to erosion, most ages indicate 2 distinct submergence rates for area (Grant, 1968, 1969). This is borne out by few previous datings (Lyon and Harrison, 1960; Frankel and Crowl, 1961; Harrison and Lyon, 1963) and by corroborative evidence. For Atlantic coast and Gulf of St. Lawrence, high tide datum has been rising at $0.5 \mathrm{ft} / 100 \mathrm{yr}$, much like rates for New England (cf. data summarized by Scholl and Stuiver, 1967) and presumably reflecting same crustal subsidence. In contrast, Fundy embayment has been submerging at almost $1 \mathrm{ft} / 100 \mathrm{yr}$, believed largely because of progressive tidal amplification. Samples GSC-922 and GSG1030 mixed with dead gas for ccunting. Dates GSC-910, 731, 899, 900, 972, 957, 930, and 975 each based on one 3-day count. NaOH-leach omitted from pretreatment of GSC-1032 and 1046. GSC-1032 dated in 2-L counter at. $1 \mathrm{~atm}$.

\title{
GSC-1089. Fort Beauséjour, New Brunswick \\ 2170 в.C.$$
\delta C^{13}=-21.6 \%
$$

$4120 \pm 130$

Wood from in situ white pine stump (id. by Wood Technology Dept., Univ. of New Brunswick Forestry Faculty) in Tantramar Marsh, S of

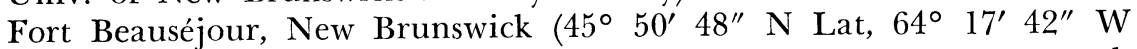
Long). Top of stump $13.72 \mathrm{ft}$ below mean sea level, top of present marsh $20.74 \mathrm{ft}$ above mean sea level (cf ref. datum for other samples from Fort Beauséjour, this list). Roots of stump imbedded in undisturbed soil profile, a podzol corresponding to soils of Tormentine catena formed on reddish brown till. Stump is one of many exposed at low water on medium 
or lower tides; surface of marsh is inundated during spring tides. Coll. 1968 by K. Langmaid, Canada Dept. Agric., Fredericton. Comment (W.B., Jr.): date in accord with GSC-930, $4040 \pm 130$, this list. Date based on one 3-day count.

\section{GSC-602. Sackville, New Brunswick}

$640 \pm 130$

Birch stump from White Birch Marsh, New Brunswick $\left(45^{\circ} 57^{\prime} \mathrm{N}\right.$ Lat, $64^{\circ} 20^{\prime} \mathrm{W}$ Long). Till, on which podzol or gleyed podzol soil of Tormentine series and upright tree stumps occur, is overlain by $1 \mathrm{ft}$ of salt marsh mud. Podzol soil and top of till $18.7 \mathrm{ft}$ above mean sea level; ground surface is at $19.7 \mathrm{ft}$. Area now protected from high tides by dikes and aboideaux. Coll. 1960 by K. Langmaid. Comment (H. A. Lee): dates buried podzol soil and contained trees.

\section{GSC-965. Sheldon Point, New Brunswick}

$13,200 \pm 200$

Marine shells (Macoma calcarea, Mya truncata and Hiatella arctica) coll. ca. $20 \mathrm{ft}$ above high-tide level in slumped cliff face ca. $0.5 \mathrm{mi} \mathrm{W}$ of Sheldon Point, W of Saint John harbor, New Brunswick $\left(45^{\circ} 13^{\prime} 30^{\prime \prime}\right.$ $\mathrm{N}$ Lat, $66^{\circ} 06^{\prime} 20^{\prime \prime} \mathrm{W}$ Long). Shells were concentrated in black layers in red clay forming cliffs. Inland, clay interdigitates with gravel. Coll. 1967 by J. Welsted. Comments (J.W.): shelly clay was probably deposited around margin of delta formed soon after deglaciation. Date agrees with $\mathrm{I}(\mathrm{GSC})-7,13,325 \pm 500$ (Radiocarbon, 1961, v. 3, p. 50); shells coll. 1958 nearby by H. A. Lee. Sample mixed with dead gas for counting.

\section{GSC-882. Pennfield, New Brunswick}

$13,000 \pm 240$

Marine pelecypod shells (Portlandia sp.) from shallow excavation for reservoir at toe of terraced, emerged delta on distal side of a major moraine, $1 \mathrm{mi} \mathrm{SW}$ of Pennfield P.O., New Brunswick $\left(45^{\circ} 05^{\prime} 50^{\prime \prime} \mathrm{N}\right.$ Lat, $66^{\circ} 45^{\prime} 15^{\prime \prime} \mathrm{W}$ Long) at alt ca. $130 \mathrm{ft}$. Coll. 1967 by N. R. Gadd. Comment (N.R.G.): intact shells, many with periostracum, suggest no transport. Shells occur in bottomset beds, but terracing of delta foreset face suggests they may relate to some time during marine regression, not to time delta top formed. Date is minimum for formation of delta topsets at ca. $250 \mathrm{ft}$, considered probable marine maximum for area, and for formation of moraine along $\mathrm{N}$ margin of delta. Moraine-delta relationships and apparent level of marine submergence at Pennfield are similar to those of Pineo Ridge in morainic systems between Cherryfield and Lubec, Maine (Borns, 1967). Date is compatible with ones in similar materials near Saint John, New Brunswick: I(GSC)-7, (13,325 \pm 500; Radiocarbon, 1961, v. 3, p. 50) and GSC-965 (13,200 \pm 200 , this list). Marine submergence of coastal Maine and Fundy coast of New Brunswick occurred a minimum of 13,000 yr B.P.; however, relationship of moraines and deltas to marine levels and to one another is not established clearly. Correlation suggested for features between Cherryfield and Saint John 
(Borns, 1967) requires further study. Sample mixed with dead gas for counting.

\section{GSC-886. Benson Corner, New Brunswick}

Marine pelecypod shells (Mytilus edulis) from silt between glaciofluvial and beach gravel in wave-modified kame $0.6 \mathrm{mi} \mathrm{S}$ of Benson Corner, on $\mathrm{W}$ side of $\mathrm{rd}$. along $\mathrm{W}$ side of Oak Bay, ca. $3 \mathrm{mi} \mathrm{N}$ of St.

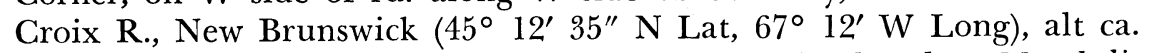
85 ft. Coll. 1967 by N. R. Gadd. Comment (N.R.G.): abundant M. edulis suggests shallow water, perhaps near limit of marine submergence (ca. $100 \mathrm{ft})$. Date is identical with GSC-795 (12,300 \pm 160; Gadd, 1968; Radiocarbon, 1968, v. 10, p. 212), on similar material and at similar alt from $\mathrm{E}$ side of St. Croix estuary a few mi S. Two dates are minimum for recession, from St. Croix estuary and from Passamaquoddy Bay to S, of persisting glacial lobe after deglaciation of adjacent coastal areas of Maine and New Brunswick; cf. GSC-882 (13,000 \pm 240 , this list; Gadd, 1969) from area where marine limit is ca. $250 \mathrm{ft}$. Outermost $50 \%$ of shell leached in pretreatment. Date based on one 3-day count.

\section{David Lake series, New Brunswick}

Gyttja and marl from newly opened trench of Grand Falls Peat Co., Ltd., in drained David Lake, ca. $12 \mathrm{mi} \mathrm{S}$ of Grand Falls near California settlement, New Brunswick ( $46^{\circ} 54^{\prime} \mathrm{N}$ Lat, $67^{\circ} 47^{\prime} \mathrm{W}$ Long). Gravel outwash from Grand Falls Moraine is overlain successively by freshwater clay, gyttja, marl, gyttja, peat, and lake sediments (Tibbetts and Kirkpatrick, 1964). Coll. 1965 by R. E. Kirkpatrick, Grand Falls, and H. A. Lee.

\section{GSC-661. David Lake, upper gyttja}

$9150 \pm 150$ 7200 в.с.

Gyttja above marl, at depth ca. $1 \mathrm{ft}$, near one end of trench.

\section{GSC-657. David Lake, marl}

$13,800 \pm 170$

Sample from base of marl, estimated depth 3 to $4 \mathrm{ft}$ below original surface of lake sediments (now stripped), in main trench. Two determinations were made; cf. Radiocarbon, 1968, v. 10, p. 209, and Table 5, this list:

$$
\begin{aligned}
& \text { inorganic portion (one 3-day count) } \\
& \text { organic portion, left after sample dissolved in } \\
& \mathrm{H}_{3} \mathrm{PO}_{4} \text { (one 3-day count) }
\end{aligned}
$$$$
13,200 \pm 170
$$

$$
\begin{array}{r}
13,800 \pm 170 \\
\mathbf{1 1 , 2 0 0} \pm \mathbf{2 0 0}
\end{array}
$$

GSC-662. David Lake, lower gyttja

9250 B.C.

Gyttja immediately below marl used for GSC-657.

General Comment (H.A.L.): marl and gyttja dated to check reliability of dates on marl in area where this material is widespread. Gyttja dates 
are in correct order; marl apparently contains older carbonate as well as older organic material. Cf. GSC-675, 11,500 \pm 180 , this list. NaOHleach omitted from pretreatment of both GSC-661 and GSC-662. GSC662 mixed with dead gas for counting.

\section{GSC-675. Siegas, New Brunswick, marl-gyttja}

$$
11,500 \pm 180
$$

9550 в.c.

Marl, aquatic shells and gyttja, at ca. $5 \mathrm{ft}$ depth in road cut for new route of Trans-Canada Hwy. at Siegas Agric. Experiment Sta. $\left(47^{\circ}\right.$ $12^{\prime} \mathrm{N}$ Lat, $67^{\circ} 57^{\prime} \mathrm{W}$ Long); from small bog in depression of calcareous slate. Marly deposit is overlain and underlain by peat. Coll. 1965 by H. A. Lee from fresh exposure. Two determinations were made; cf. Radiocarbon, 1968, v. 10, p. 209, and Table 5, this list:

$$
\begin{array}{lr}
\begin{array}{l}
\text { inorganic portion } \\
\text { organic portion (left after sample }
\end{array} & 12,100 \pm 170 \\
\text { dissolved in } \mathrm{H}_{3} \mathrm{PO}_{4} & 11,500 \pm 180
\end{array}
$$

Comment (H.A.L.): sample was intended to check validity of date on marl containing aquatic shells vs. gyttja; agreement between organic and inorganic portions is only fair; cf. GSC-18 (9820 \pm 130 ; Radiocarbon, 1962, v. 4, p. 16), a date on wood within gravel along Siegas R.

\section{GSC-856. Rivière Caouette, Quebec}

$9180 \pm 180$

Charcoal fragments enclosed in oxidized pebbly, silty-clay, 4 to 6 $\mathrm{ft}$ below original surface in cut on $\mathrm{N}$ side of Domtar Newsprint Rd. 7a, NW side of Rivière Caouette, $200 \mathrm{ft} \mathrm{NE}$ of junction of this river with tributary from Lac Caouette, Quebec $\left(45^{\circ} 47.25^{\prime} \mathrm{N}\right.$ Lat, $70^{\circ} 29.5^{\prime}$ W Long). Coll. 1967 by W. W. Shilts, Syracuse Univ., Syracuse, New York. Comment (W.W.S.): enclosing material originally thought to be till, but later excavations revealed it to overlie texturally distinct lodgment till with strong NW fabric. Striae $100 \mathrm{ft}$ from coll. site are at $130^{\circ}$. Pebbly silt now is thought to be colluvium deposited soon after denudation by forest fires. NaOH-leach omitted from sample pretreatment. Sample mixed with dead gas for counting.

\section{GSC-908. Rivière Chaudière, Quebec}

Wood fragment from laminated lake silt, $\mathrm{E}$ face of artificial channel cut for Rivière Chaudière through $\mathrm{E}$ end of Gayhurst Dam, $400 \mathrm{ft}$ downstream from dam, Quebec $\left(45^{\circ} 45^{\prime} \mathrm{N}\right.$ Lat, $70^{\circ} 47.5^{\prime} \mathrm{W}$ Long). Sample, $12 \mathrm{ft}$ above river, surrounded by undisturbed laminae. Silt is overlain locally by fluvial gravel and by till. Coll. 1967 by W. W. Shilts. Comment (W.W.S.): significance of date unknown; artificial channel is 5 yr old. Sample mixed with dead gas for counting. 
GSC-936. L'Avenir, Quebec

$12,000 \pm 230$

10,050 B.c.

Marine pelecypod shells (Macoma balthica $90 \%$, Hiatella arctica $8 \%$, Mya sp. $1 \%$, Yoldia sp. $1 \%$ ), coll. in gravel pit from 8 to $12 \mathrm{ft}$ depth in pebbly gravel and sand $2 \mathrm{mi} \mathrm{NNW}$ of L'Avenir, Quebec $\left(45^{\circ} 47^{\prime} \mathrm{N}\right.$ Lat, $72^{\circ} 16^{\prime} \mathrm{W}$ Long), alt ca. $400 \mathrm{ft}$. Coll. 1967 by B. C. McDonald. Comment (B.C.M.): from same site as GSC-505, 11,880 \pm 180 , (Radiocarbon, 1967, v. 9, p. 159) but redated because GSC-505 was older than other Champlain Sea shell dates (cf. Gadd, 1964; McDonald, 1968). GSC-936 was handpicked to avoid secondary carbonate, and outermost $50 \%$ of shells was removed by leaching. Date supports initial determination and indicates that Champlain Sea was in existence by ca. 12,000 B.P. (cf. GSC-475-2, $11,500 \pm 160$, this list).

\section{GSC-475-2. Ste-Christine, Quebec}

$$
11,500 \pm 160
$$

Marine pelecypod shells (mostly Hiatella arctica, but fragments of Macoma sp., Yoldia sp., and Mytilus edulis) from silt $5 \mathrm{ft}$ below surface, in bottom of small, unnamed stream, $0.5 \mathrm{mi} \mathrm{SW}$ of village of SteChristine, Quebec ( $45^{\circ} 36^{\prime} \mathrm{N}$ Lat, $72^{\circ} 26^{\prime} 30^{\prime \prime} \mathrm{W}$ Long), alt ca. $475 \mathrm{ft}$. Shell site is $0.25 \mathrm{mi} \mathrm{NW}$ along gently sloping marine plain from beach at $510 \mathrm{ft}$. Marine limit marked by adjacent beach at $540 \mathrm{ft}(165 \mathrm{~m})$. Coll. 1965 by B. C. McDonald. Comment (B.C.M.): specimens of Hiatella, Macoma, and Yoldia were found articulated and in growth position, so shells probably not reworked. Shells are among highest on SE shore of Champlain Sea; they are probably related to sea-level stand at $510 \mathrm{ft}$ or $540 \mathrm{ft}$. Date should indicate age of early phase of marine invasion of St. Lawrence Lowlands. Sample redated to check on possible discrepancy between GSC-475 (11,530 \pm 160$)$ and GSC-505 (11,880 \pm 180 , both in Radiocarbon, 1967, v. 9, p. 159-160); cf. also GSC-936, 12,000 \pm 230 , this list. Date agrees with original determination. One preparation was made, after outermost $50 \%$ removed by leaching (compared to normal $20 \%$ for GSC-475), and counted first in 5-L counter, then in 2-L counter:

5-L counter, one 1-day count

$$
\begin{array}{r}
11,300 \pm 170 \\
11,500 \pm 160 \\
\mathbf{8 6 3 0} \pm \mathbf{1 6 0}
\end{array}
$$$$
\text { 2-L counter, one 3-day count }
$$

\section{GSC-951. Lac-Saint-Jean, Québec}

Marine shells (Hiatella arctica) from stony, silty clay overlying esker gravel, alt ca. $110 \mathrm{~m}, 3.4 \mathrm{mi} \mathrm{SE}$ of St-Félicien, Québec $\left(48^{\circ} 36^{\prime} 55^{\prime \prime} \mathrm{N}\right.$ Lat, 72 $23^{\prime} 30^{\prime \prime} \mathrm{W}$ Long); many shells whole and paired. Coll. 1967 by J. C. Dionne, Dept. of Forestry and Rural Development, Québec. Comment (J.C.D.): date is minimum for Laflamme Gulf submergence in W part of Lac-Saint-Jean area, but is significantly younger than dates on marine shells from E Lac-Saint-Jean; e.g., 10,250 \pm 350 (Gif-424) on shells at alt $113 \mathrm{~m}$ in sandy beaches at Metabetchouan, $20 \mathrm{mi}$ SE of StFélicien (Lasalle and Rondot, 1967; cf. also Lasalle, 1965, 1966; Radio- 
carbon, 1966, v. 8, p. 102). Pretreatment involved leaching of only outermost $10 \%$ of shell.

\section{GSC-1022. Chacoura slide, Quebec}

$3960 \pm 130$

2010 B.c.

Hemlock Ontario) Chtario) 6 to $8 \mathrm{ft}$ below top of "flow-slide" on $\mathrm{E}$ bank of Rivière Chacoura, $3 \mathrm{mi} \mathrm{N}$ of Quebec Rte. 2 at Louiseville, Quebec $\left(46^{\circ} 18^{\prime} \mathrm{N}\right.$ Lat, $72^{\circ} 56^{\prime} 30^{\prime \prime} \mathrm{W}$ Long). Alluvium overlying wood and peat is underlain by undisturbed gray marine clay (cf. Gadd and Karrow, 1960). Coll. 1966 by P. F. Karrow, Univ. of Waterloo, Waterloo. Comment (P.F.K.): date, oldest for a "flow-slide" in Quebec, is maximum for slide. Geomorphic evidence suggests presence of slides of substantially greater age. GSC-550 (1140 \pm 150, Radiocarbon, 1967, v. 9, p. 160), dates a similar "flow-slide" near Ottawa, Ontario.

\section{GSC-985. Place Victoria, Montreal, Quebec}

$6750 \pm 140$

Silty gyttja with freshwater molluscs from excavation for subway sta. at SW corner of Beaver Hall Hill and Vitre Sts., Montreal, Quebec $\left(45^{\circ} 29^{\prime} 40^{\prime \prime} \mathrm{N}\right.$ Lat, $73^{\circ} 33^{\prime} 50^{\prime \prime} \mathrm{W}$ Long), alt ca. $30 \mathrm{ft}$. Sandy peat and gyttja are enclosed in silt and sand beds overlying sand and gravel on bedrock. Sample $16.5 \mathrm{ft}$ below ground. Coll. 1966 by J. A. Elson and Q. H. J. Gwyn, McGill Univ., Montreal; subm. by J. Terasmae. Comment (J.A.E.): sediments accumulated in shallow lake formed when St. Lawrence R. abandoned a channel now in St. Vitre-Craig St. area of old Montreal. Date is maximum for present course of river at Montreal. $\mathrm{NaOH}$-leach omitted from sample pretreatment. Date based on one 4-day count.

\section{GSC-842 Meach Lake, Gatinean Park, Quebec \\ 9650 B.c.}

Shells (Hiatella arctica and Macoma balthica) at alt $557 \mathrm{ft}, 0.5 \mathrm{mi} \mathrm{E}$ of $S$ end of Meach Lake, Gatineau Park, Quebec $\left(45^{\circ} 30^{\prime} 30^{\prime \prime}\right.$ N Lat, $75^{\circ}$ $51^{\prime} 30^{\prime \prime} \mathrm{W}$ Long), from pit exposure in sand $40 \mathrm{ft}$ thick overlying silt. Marine limit believed slightly higher than top of sand at $590 \mathrm{ft}$. Coll. 1967 by J. T. Buckley. Comment (J.T.B.): date is minimum for deglaciation of Gatineau R. valley; probably relates to time when Champlain Sea stood at ca. $600 \mathrm{ft}$ at Meach Lake (cf. Buckley, 1968; Gadd, 1964). Outermost $50 \%$ of shells leached. Date based on one 4-day count.

\section{GSC-982. Mahon Lake, Quebec \\ $11,300 \pm 180$ \\ Marine shells (Macoma sp) from fine gravel in stream-bed cut in silty} clay, alt 508 to $525 \mathrm{ft}, 0.75 \mathrm{mi} \mathrm{S}$ of Mahon Lake and ca. $2.5 \mathrm{mi} \mathrm{NNE}$ of Ste-Cécile de Masham, Quebec (45 $45^{\circ} \mathrm{N}$ Lat, $76^{\circ} 01^{\prime} 15^{\prime \prime} \mathrm{W}$ Long). Shells believed to derive from gravel at alt 550 to $600 \mathrm{ft}$. Coll. $1967 \mathrm{by}$ J. T. Buckley. Comment (J.T.B.): date accords with GSC-842 (11,600 \pm 
150 , this list), coll. at $557 \mathrm{ft}$ ca. $12.5 \mathrm{mi}$ to SE. Only outermost $10 \%$ of small $(12 \mathrm{~g})$ sample leached. Sample mixed with dead gas for counting. Date based on one 3-day count.

\section{Twin Elm series, Ontario}

Marine brown algae (kelp) and shells from Orr Unsworth Ltd. gravel pit $12 \mathrm{mi} \mathrm{SE}$ of Ottawa center, and ca. $3.5 \mathrm{mi} \mathrm{NE}$ of Richmond, in Nepean township. Pit is at SW corner of Moodie Drive and road to Twin Elm, Ontario (45 $14^{\prime} \mathrm{N}$ Lat, $75^{\circ} 47^{\prime} \mathrm{W}$ Long). Sands washed from morainic ridge during Champlain Sea episode contain layer of marine algae. Marine shells occur in layer below algal bed and scattered through sand above it (Mott, 1968). Coll. 1965 and 1966 by R. J. Mott, J. Terasmae, and T. W. Anderson.

\section{GSC-588. Twin Elm, lower shells}

$10,880 \pm 160$

Abundant shells (Macoma balthica) formed a layer 3 to 4 in. thick in gently dipping gray, unoxidized and unleached lower sands below water table. This is lowest sample dated.

\section{GSC-570. Twin Elm, kelp}

$10,800 \pm 150$

Marine brown algae (kelp) formed 2 layers up to 3 in. thick, or several thin layers near top of lower sands; layer is ca. 30 to $35 \mathrm{ft}$ below original ground level.

\section{GSC-587. Twin Elm, upper shells}

$10,620 \pm 200$

Marine shells, (mainly Macoma balthica), dispersed throughout upper, steeply bedded, leached sands.

General Comment (R.J.M.): date on kelp corroborates dates on marine shells and substantiates validity of previous Champlain Sea shell and bone dates from Ottawa area; cf. L-604A $(10,700 \pm 200)$ and L-604B $(10,550$ \pm 200; both in Radiocarbon, 1961, v. 3, p. 150) and GSC-454 (10,420 \pm 150; Radiocarbon, 1966 , v. 8 , p. 103). NaOH-leach omitted from pretreatment of GSC-570; date based on one 3-day count. For GSC-587 outer $50 \%$ of shells removed before dating; sample mixed with dead gas for counting.

\section{GSC-1013. Maitland, Ontario}

$11,800 \pm 210$

9850 в.c.

Marine shells (Macoma balthica) from shallow gravel at Brockville Chemical Works $2 \mathrm{mi} \mathrm{NE}$ of Maitland, Ontario $\left(44^{\circ} 40^{\prime} \mathrm{N}\right.$ Lat, $75^{\circ} 36^{\prime}$ $\mathrm{W}$ Long). Gravel occurs as beach or bar deposits of Champlain Sea along crest of long till ridge, alt $340 \mathrm{ft}(65 \mathrm{ft}$ below theoretical marine limit). Coll. 1967 by E. P. Henderson. Comment (E.P.H.): date suggests gravels near Maitland may be oldest deposits so far assoc. with $\mathrm{W}$ parts of Champlain Sea (Henderson, 1969). Previously a shell sample N of Ottawa near Meach Lake dated 11,600 \pm 150 yr (GSC-842, this list; Buckley, 1968) was oldest date obtained from W Champlain Sea mater- 
ials. When coll., shells nearest yet found to alt of Champlain Sea water plane at its maximum $W$ extension. Subsquently a few marine shell fragments have been found at Yule Sta., $19 \mathrm{mi} \mathrm{NW}$, only $35 \mathrm{ft}$ below marine limit. Only outermost $5 \%$ of shells leached due to small sample size $(7.0 \mathrm{~g})$. Sample mixed with dead gas for counting. Date based on one 4-day count in 2-L counter at 1 atm.

GSC-1028. Arthur, Ontario 8850 B.c.

Marly gyttja coll. with piston sampler from base of peat sequence, depth 638 to $643 \mathrm{~cm}$ in Wylde Lake Bog, ca. $8 \mathrm{mi} \mathrm{NE}$ of Arthur, Ontario $\left(43^{\circ} 54^{\prime} 15^{\prime \prime} \mathrm{N}\right.$ Lat, $80^{\circ} 24^{\prime} 30^{\prime \prime} \mathrm{W}$ Long), at alt $<1600 \mathrm{ft}$. Coll. 1968 by T. W. Anderson. Comment (T.W.A.): pollen from sample shows date represents time for spruce decline and jackpine invasion; it agrees closely with date on spruce decline for bog near Heidelberg (GSC-1006, 10,700 \pm 160 , this list). NaOH-leach omitted from sample pretreatment. Date based on one 3-day count.

\section{GSC-1006. Heidelberg, Ontario}

Gyttja coll. with Hiller sampler from base $(220$ to $230 \mathrm{~cm}$ depth) of organic material in peat-gyttja sediment sequence in bog $1.7 \mathrm{mi} \mathrm{S}$ of

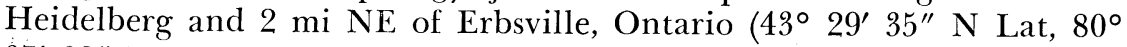
$37^{\prime}$ 02" W Long). Coll. 1967 by B. A. Sreenivasa and T. W. Anderson, Univ. of Waterloo, Waterloo. Comment (B.A.S.): date is minimum for Cary Drift on top of Waterloo morainic complex and provides age for spruce decline and pine rise in pollen profile. It accords with date of 11,950 \pm 350, I(GSC)-29 (Radiocarbon, 1961, v. 3, p. 49; Karrow et al., 1961; Karrow, 1963), on basal gyttja from Crieff Kettle Bog, on Galt moraine ca. $14 \mathrm{mi} \mathrm{S}$, which relates to spruce maximum on pollen diagram by J. Terasmae. A similar date (GSC-1028, 10,800 \pm 180 , this list) has been obtained for spruce decline at Wylde Lake Bog. NaOH-leach omitted from sample pretreatment. Sample mixed with dead gas for counting. Date basd on one 3-day count.

\section{Plum Point series, Ontario}

Samples of driftwood and peat balls from buried beach deposit 20 $\mathrm{ft}$ deep in gravel pit on Lake Erie shore $0.5 \mathrm{mi}$ NE of Plum Point, Ontario (42 $36^{\prime} 45^{\prime \prime} \mathrm{N}$ Lat, $81^{\circ} 23^{\prime} 30^{\prime \prime} \mathrm{W}$ Long). Beach gravel overlies, successively, glaciofluvial gravel and Port Talbot Interstadial deposits, and is overlain, successively, by Catfish Creek Drift, Port Stanley Drift, and late-Wisconsin glaciolacustrine sediments. Coll. 1967 by F. Mayr; subm. by A. Dreimanis, both of Univ. of Western Ontario, London.

GSC-770. Plum Point, Ontario, driftwood

Comment (A.D.): sample coll. to date beach deposit believed of Plum Point Interstadial age $(24,000$ to $28,000 \mathrm{yr}$, Dreimanis et al., 1966), but date indicates wood probably is reworked Port Talbot Interstadial material in spite of its fresh appearance. Pretreatment (by A.D.) in- 
cluded boiling in $\mathrm{NaOH}$ solution. Port Talbot wood usually produces a strong brown humic stain, so only wood with little brown staining was submitted. Date based on one 3-day count.

\section{GSC-993-2. Plum Point, Ontario, peat ball}

$46,400 \pm 940$

Comment (A.D.): peat ball is probably reworked from Port Talbot II Interstadial deposits. Pollen content of peat (5 samples investigated by A. A. Berti, Univ. of Western Ontario) resembles closely that of Port Talbot II beds: main pollen are spruce (49 to 57\%) and jackpine (36 to $44 \%$ ). Date is in good agreement with other finite Port Talbot Interstadial dates from Plum Point-Port Talbot area, ranging from 42,000 to 48,000 yr B.P. (Dreimanis et al., 1966 and 2 unpub. Groningen dates). Two determinations were made:

GSC-993 (NaOH-leach omitted from sample pretreatment; one 3-day count in 2-L counter)

GSC-933-2 (one 3-day count and one 1-day count in 5 - $\mathrm{L}$ counter at $4 \mathrm{~atm})$

$$
\begin{aligned}
& 46,400 \pm 940 \\
& \mathbf{1 8 , 5 0 0} \pm \mathbf{2 0 0} \\
& \mathbf{1 6 , 5 5 0} \text { в.C. }
\end{aligned}
$$

\section{GSC-994. Port Glasgow, Ontario}

Plant detritus from beach or nearshore sand, at $11 \mathrm{ft}$ depth, in Lake
bluff at Port Glasgow, Ontario $\left(42^{\circ} 30^{\prime} 35^{\prime \prime} \mathrm{N}\right.$ Lat, $81^{\circ} 36^{\prime} 30^{\prime \prime}$ W Long). Sand overlies Port Stanley Till; plant detritus was concentrated in depressions in till surface. Coll. 1967 by F. Mayr; subm. by A. Dreimanis. Comment (A.D.): as plant detritus occurs $70 \mathrm{ft}$ above Lake Erie level and ca. $75 \mathrm{ft}$ below Lake Warren level, it was believed to belong to transitional phase between Lake Warren and Early Lake Erie, or to low level phase assoc. with Lake Arkona. Date obtained is improbable as ice margin was in S Ohio then (Goldthwait $e t$ al., 1965); admixture of some old plant remains, most probably from Port Talbot Interstadial deposits, is suggested. $\mathrm{NaOH}$-leach omitted from sample pretreatment. Date based on one 3-day count.

\section{The Albany Forks series, Ontario}

Gyttja and peat from 2 localities near The Albany Forks, Ontario. Coll. 1967 with Davis piston sampler by J. Terasmae and R. J. Mott.

$7140 \pm 170$

GSC-831. The Albany Forks, 520 ft 5190 B.c.

Gyttja and peat from $412 \mathrm{~cm}$ below bog surface, overlying silty clay, alt ca. $520 \mathrm{ft}, 22 \mathrm{mi} \mathrm{NNW}$ of The Albany Forks $\left(51^{\circ} 23^{\prime} \mathrm{N}\right.$ Lat, $84^{\circ}$ $31^{\prime}$ W Long).

\section{GSC-885. The Albany Forks, 550 ft}

Gyttja and peat from $450 \mathrm{~cm}$ below surface, overlying sand and gravel, near small lake ca. $30 \mathrm{mi} \mathrm{NW}$ of The Albany Forks $\left(51^{\circ} 28^{\prime} \mathrm{N} \mathrm{Lat}\right.$, 
$84^{\circ} 48^{\prime} \mathrm{W}$ Long), at alt ca. $550 \mathrm{ft}$. Lake is on one of numerous curving features of unknown origin which transect, and are higher than, parallel shorelines in area (highest at ca. $520 \mathrm{ft}$ alt).

General Comment (B. G. Craig): GSC-831 is ca. $50 \mathrm{ft}$ above marine limit and provides minimum date for deglaciation of region and beginning of accumulation of organic sediment; cf. GSC-487 (7660 \pm 140 ) and GSC-309 (7150 \pm 140 ; both in Radiocarbon, 1966, v. 8, p. 105-106), GSC-624 (7380 \pm 140; Radiocarbon, 1967, v. 9, p. 162), and GSC-670 (7560 \pm 180 ; Radiocarbon, 1968, v. 10, p. 215), other similar dates relating to draining of Glacial Lake Barlow-Ojibway. For summaries of ages on oldest marine shells in area see Craig (1969). NaOH-leach omitted from pretreatment of both samples. GSC-885 mixed with dead gas for counting.

\section{GSC-1011. Severn River, Ontario}

Peat from NW bank of Severn R., ca. $5.5 \mathrm{mi}$ upstream from confluence with Fawn R. (55 $18^{\prime} \mathrm{N}$ Lat, $88^{\circ} 26^{\prime} \mathrm{W}$ Long), at alt ca. $200 \mathrm{ft}$, $13 \mathrm{ft}$ above river level. Peat occurred as lenses 6 in. long in clayey sand within $10-\mathrm{ft}$ thick unit of stratified sediments underlying $20 \mathrm{ft}$ of till. Wood fragments as long as 0.75 in. were assoc. with peat. Coll. 1967 by B. C. McDonald. Comment (B.C.M.): peat, probably of interglacial age, is probably correlative with Missinaibi beds dated at $>53,000$ (Gro1435; Terasmae and Hughes, 1960a). Other dates on Missinaibi beds are cited by Terasmae (1958) and McDonald (1969); cf. also GSC-892, $>37,000$, this list. $\mathrm{NaOH}$-leach omitted from sample pretreatment. Date based on one 4-day count.

\section{Hudson Bay Lowland series, Ontario and Manitoba}

Marine pelecypod shells from 7 localities $\mathrm{S}$ and $\mathrm{W}$ of Hudson Bay, Ontario and Manitoba.

\section{GSC-915. Kabinakagami River, Ontario}

Whole shells (Hiatella arctica), many paired, in silty clay from river bank sec., alt ca. $325 \mathrm{ft}$, ca. 50 to $75 \mathrm{ft}$ below marine limit on Kabinakagami R., ca. $15 \mathrm{mi}$ S of Kenogami R., Ontario $\left(50^{\circ} 13^{\prime} \mathrm{N}\right.$ Lat, $84^{\circ} 14^{\prime}$ W Long). Coll. 1967 by B. C. McDonald.

\section{GSC-897. Nagagami River, Ontario}

Whole shells (Hiatella arctica), many paired, in silt from river bank sec., alt ca. $345 \mathrm{ft}$, ca. 50 to $75 \mathrm{ft}$ below marine limit, on Nagagami R., ca. $14 \mathrm{mi} \mathrm{S}$ of Kenogami R., Ontario (50 $13^{\circ} \mathrm{N}$ Lat, $84^{\circ} 18^{\prime} \mathrm{W}$ Long). Coll. 1967 by Q. H. J. Gwyn.

\section{GSC-880. Kapiskau River, Ontario}

Marine pelecypod shells (Macoma calcarea), many paired, in clayey silt in river bank, alt $400 \mathrm{ft}$, ca. $100 \mathrm{ft}$ below marine limit, on Kapiskau 
R., $32 \mathrm{mi}$ SE of Mississa Lake, Ontario ( $51^{\circ} 56^{\prime} \mathrm{N} \mathrm{Lat,} 84^{\circ} 32^{\prime} \mathrm{W}$ Long). Coll. 1967 by B. G. Craig.

\section{GSC-872. Ekwan River, Ontario}

Whole shells and fragments (Mya truncata) in sand and silt from river bank, alt ca. $400 \mathrm{ft}$, ca. $125 \mathrm{ft}$, ca. $125 \mathrm{ft}$ below marine limit, on Ekwan R., Ontario (53 $32^{\prime} \mathrm{N}$ Lat, $86^{\circ} 03^{\prime} \mathrm{W}$ Long). Coll. 1967 by L. M. Cumming.

\section{GSC-877. Fawn River, Ontario}

$7400 \pm 140$

Marine pelecypod shells (Hiatella arctica), many paired, in sand from river bank, alt ca. $450 \mathrm{ft}$, ca. $50 \mathrm{ft}$ below marine limit, on Fawn R., 14 mi above mouth of Fat R., Ontario $\left(54^{\circ} 29^{\prime} \mathrm{N}\right.$ Lat, $88^{\circ} 16^{\prime} \mathrm{W}$ Long). Coll. 1967 by B. C. McDonald.

\section{GSC-896. 'Old Beach' Creek, Manitoba}

$8530 \pm 220$

Marine pelecypod shell fragments (mainly Hiatella arctica and Macoma sp.) in beach sand, river bank, alt $410 \mathrm{ft}$, ca. $35 \mathrm{ft}$ below marine limit, on Old Beach Creek 52 mi S of mouth of Kaskattama R., Manitoba $\left(56^{\circ} 18^{\prime} \mathrm{N}\right.$ Lat, $90^{\circ} 24^{\prime} \mathrm{W}$ Long). Coll. 1967 by B. G. Craig and B. C. McDonald.

\section{GSC-878. Hayes River, Manitoba}

$7570 \pm 140$

Marine pelecypod shells (Hiatella arctica) in living position in silty clay of river bank, alt ca. $375 \mathrm{ft}, 25$ to $50 \mathrm{ft}$ below marine limit, on Hayes R., 2 mi above mouth of Fox R., Manitoba $\left(56^{\circ} 02^{\prime} 20^{\prime \prime} \mathrm{N}\right.$ Lat, 93 17' W Long). Coll. 1967 by M. C. McDonald. General Comment (B.G.C.): this series comprises dates on several shell collections near marine limit across Hudson Bay Lowland to determine time of deglaciation and marine invasion. Along with $\mathrm{I}(\mathrm{GSC})-14(7875 \pm 200$; Terasmae and Hughes, 1960b), I(GSC)-8 (6975 \pm 250; Lee, 1959) and GSC-289 $(6830 \pm 170$; Craig, 1965b), present series indicates that samples from SW of James Bay (ca. 7900 to 7400 B.P.) are clearly older than those from W and NW of Hudson Bay (ca. 6900 to 6600 в.P.; Craig, 1969). Age of GSC-896 $(8530 \pm 220)$ is not compatible with rest of series; as shells are found throughout area in deposits that predate Tyrrell Sea deposits it is assumed that this coll. is both redeposited and contaminated (cf. also GX-1063, $8010 \pm 95$, on shells $50 \mathrm{mi}$ SW of Churchill; Wagner, 1967). For GSC-896 only outermost $10 \%$ of shells removed by leaching; sample mixed with dead gas for counting. Dates for GSC-897, 880, 877, and 878 each based on one 3-day count. Dates for GSC-915, 872, and 896 each based on one 4-day count.

\section{GSC-892. Echoing River, Manitoba}

Wood from bank of unnamed tributary of Echoing R., 22.4 mi NNE of confluence of Echoing and Sturgeon Rivers (55 $50^{\prime} 30^{\prime \prime} \mathrm{N} \mathrm{Lat,} 91^{\circ}$ 
15' W Long), at alt ca. $400 \mathrm{ft}, 28.5 \mathrm{ft}$ above stream level. Coll. 1967 by B. G. Craig. Wood enclosed in laminated organic-rich silt overlying 3 in. peat and is part of sequence of stratified sediments at least $17 \mathrm{ft}$ thick underlying $18 \mathrm{ft}$ till. Comment (B. C. McDonald): wood is probably part of widely exposed unit in Hudson Bay Lowland that has been interpreted as being of interglacial age; cf. GSC-1011 ( $>41,000$, this list), GSC-83 (>35,000; Radiocarbon, 1963, v. 5, p. 45; McDonald, 1969).

\section{GSC-984. Morden, Manitoba}

$5050 \pm 180$

Wood fragments retrieved by sidewall sampler, 19 to $20 \mathrm{ft}$ depth, from drill hole $2 \mathrm{mi} \mathrm{E}$ and $2.5 \mathrm{mi} \mathrm{N}$ of Morden, Manitoba, SW12-23-3-5 WP $\left(49^{\circ} 15^{\prime} \mathrm{N}\right.$ Lat, $98^{\circ} 00^{\prime} \mathrm{W}$ Long). Sample from base of $20 \mathrm{ft}$-thick clay-rich silt and fine sand unit overlying lacustrine clays. Coll. 1967 by J. E. Wyder. Comment (J.E.W.): sample dated to obtain age between 2 phases (I and II) of Lake Agassiz. Young date may represent, instead, earliest flooding of Lake Agassiz plain by postglacial Red R. Sample mixed with dead gas for counting. Date based on one 4-day count.

\section{Rossendale series, Manitoba}

Alluvial and lacustrine silt and clay containing plant detritus and shells underlie an Assiniboine Valley terrace at $1050 \mathrm{ft}$ level ca. $4 \mathrm{mi}$ $S$ of Rossendale, Manitoba, NE 1/4 LSD9 sec. 17, tp. 9, rge. 9 W1 $\left(49^{\circ}\right.$ $45^{\prime} \mathrm{N}$ Lat, $98^{\circ} 39^{\prime} \mathrm{W}$ Long). Samples from fresh roadcut and adjacent gully exposing a total of ca. $70 \mathrm{ft}$ of sediment below terrace surface. Coll. 1966 and 1967 by R. W. Klassen.

\section{GSC-902. Rossendale, plant detritus}

$$
10,600 \pm 150
$$

8650 B.C.

Plant detritus from lowest silty unit containing organic material, ca. $60 \mathrm{ft}$ below terrace surface.

GSC-870. Rossendale, lower wood

$10,000 \pm 150$

Wood from base of clay unit, ca. $28 \mathrm{ft}$ below terrace surface.

$$
8050 \text { B.C. }
$$

GSC-797. Rossendale, upper wood 7750 B.C.

Wood from clayey silt unit, ca. $16 \mathrm{ft}$ below terrace surface.

\section{GSC-689. Rossendale, freshwater clams}

Freshwater clam shells from old exposure of same unit as GSC-797, at depths from 5 to $15 \mathrm{ft}$ below terrace surface. Two determinations were made after removal of outer $20 \%$ of shells:

outer fraction (21 to $60 \%$ leach), two l-day counts $10,720 \pm 160$

inner fraction (61 to $100 \%$ leach), one 3-day count $10,920 \pm 150$

General Comment (R.W.K.): wood and plant detritus dates record fluctuations in level of Lake Agassiz subsequent to initial drop in level of Lake 
Agassiz I. Dates on wood and plant detritus are internally consistent and indicate that shell date is $1000 \mathrm{yr}$ too old; younger terrace ca. $10 \mathrm{mi}$ up-valley and $70 \mathrm{ft}$ lower contains shells of similar age (GSC-492, 10,670 \pm 160; Klassen, 1967; Radiocarbon, 1967, v. 9, p. 166). Date for GSC-797 based on one 4-day count.

\section{GSC-987. Bliss Gravel Pit, Fort Qu'Appelle, Saskatchewan}

Aquatic and terrestrial mollusc shells from Bliss Gravel Pit on SW side of Fort Qu'Appelle, Saskatchewan in sec. 18, tp. 21, rge. 13, W 2nd mer. ( $50^{\circ} 46^{\prime} \mathrm{N}$ Lat, $103^{\circ} 48^{\prime} \mathrm{W}$ Long), alt ca. $1615 \mathrm{ft}$. Shells from gravel and sand beds, $50 \mathrm{ft}$ thick, containing abundant vertebrate fossils; overlain by thick drift including 2 tills and underlain by one or more tills. The intertill deposit is thought to be of Sangamon age. Coll. 1967 by E. Khan, Punjab Univ., Chandigarh, India and A. M. Stalker. Comment: only outermost $5 \%$ removed due to small sample size (ca. $7 \mathrm{~g}$ ). Sample mixed with dead gas for counting. Date based on one 4-day count.

\section{GSC-1041. Kenaston No. 2, Saskatchewan $\quad \mathbf{3 6 , 0 5 0}$ в.c.}

Wood in gyttja 19 to $23 \mathrm{ft}$ below surface under one till in drill hole Kenaston No. 2, SW11-24-29-3-W3, Saskatchewan $\left(50^{\circ} 30^{\prime}\right.$ N Lat, $106^{\circ}$ 18' W Long). Coll. 1945 by S. C. Collins; subm. by E. A. Christiansen, Saskatchewan Research Council, Saskatoon. Another wood sample from drill hole was dated at $>30,000$ (S-166). Comment (E.A.C.): wood is overlain by Battleford Formation, a thin till occurring in W-central Saskatchewan (Christiansen 1968a, 1968b). Hiatus prior to deposition of this till began at least 38,000 yr ago. Dated in 5-L counter at $4 \mathrm{~atm}$. Date based on one 1-day count.

GSC-978. Patience Lake, Saskatchewan

Wood from intertill sand bed at 114 to $156 \mathrm{ft}$ depth in mine shaft near Patience Lake, Saskatchewan, LSD11, sec. 9, tp. 36 rge. 3, W3 (52 $05^{\prime} \mathrm{N}$ Lat, $106^{\circ} 20^{\prime} \mathrm{W}$ Long). Sand bed is overlain by 2 tills. Coll. 1967 by L. L. Price; subm. by R. W. Klassen.

\section{Medicine Hat series, Alberta (III)}

GSC-847. 'Golden Valley Bluff'

Poorly-preserved plant fragments from $\mathrm{S}$ end of 'Golden Valley Bluff', on E bank South Saskatchewan R., directly beyond $\mathrm{N}$ limit of Medicine Hat in SW $1 / 4$, sec. 33, tp. 12, rge. 5, W 4 th mer. $\left(50^{\circ} 02^{\prime} 20^{\prime \prime}\right.$ $\mathrm{N}$ Lat, $110^{\circ} 38^{\prime} 15^{\prime \prime} \mathrm{W}$ Long). Ca. $12 \mathrm{ft}$ above river (alt ca. $2175 \mathrm{ft}$.), near base of $125 \mathrm{ft}$-thick alluvium deposit and overlain by much drift including 2 or more till sheets. Coll. 1966 by A. M. Stalker.

GSC-876. 'Surprise Bluff' $>36,000$

Aquatic and terrestrial mollusc shells (mostly Sphaerium sp.), from $S$ bank South Saskatchewan R. near W edge of Medicine Hat, in SE1/4, 
sec. 34, tp. 12, rge. 6 , W 4 th mer. (50 $02^{\prime} 10^{\prime \prime} \mathrm{N}$ Lat, $110^{\circ} 44^{\prime} \mathrm{W}$ Long), and $80 \mathrm{ft}$ above river at alt ca. $2250 \mathrm{ft}$. In alluvium overlying fine gravel containing abundant vertebrate fossils and overlain by thick drift that includes 3 till sheets. Coll. 1967 by A. M. Stalker.

General Comment (A.M.S.): GSC-847 is from same deposit as GSC-543, $>46,700$ (Radiocarbon, 1967, v. 9, p. 168-169), but from slightly higher stratigraphically and $3 \mathrm{mi} \mathrm{S}$. Deposit now thought to be of Yarmouthian or greater age (Stalker, 1969a). GSC-876 is from same deposit as GSC-780, $>30,000$ (Radiocarbon, 1968, v. 10, p. 219) $8 \mathrm{mi} \mathrm{SW}$. Deposit now thought to be of Sangamon age. GSC-847 based on one 3-day count. For GSC-876 only outermost $10 \%$ removed due to small sample size $(15 \mathrm{~g})$; sample mixed with dead gas for counting.

GSC-888. 'Rattlesnake Bluff', Taber, Alberta

$>37,000$

Pieces of wood from 'Rattlesnake Bluff' on E bank Oldman R., 8 mi NNE of Taber, Alberta, in SE1/4, sec. 24, tp 11, rge. 16, W 4th mer. $\left(49^{\circ} 55^{\prime} 30^{\prime \prime} \mathrm{N}\right.$ Lat, $112^{\circ} 04^{\prime} \mathrm{W}$ Long). Wood is from $10 \mathrm{ft}$ above base of $30 \mathrm{ft}$-thick sec. of alluvial sand and $60 \mathrm{ft}$ above river, alt ca. $2430 \mathrm{ft}$. Sand underlies $60 \mathrm{ft}$ drift, including 2 till sheets, and overlies till and preglacial gravel. Coll. 1967 by A. M. Stalker. Comment (A.M.S.): GSC$728(35,980 \pm 1060$; Radiocarbon, 1968 , v. 10 , p. 220), came from same site. This date probably was affected by abundant, modern rootlets; GSC-888 is judged more reliable. Alluvium appears to be continuation of bed that yielded human bones near Taber, and is of either mid-Wisconsin or Sangamon age. Sample mixed with dead gas for counting.

\section{Castle River series, Alberta (III)}

Samples from 'Mountain Mill Bluff' on S bank Castle R., ca. $6 \mathrm{mi}$ W of town of Pincher Creek, Alberta, in SE1/4 sec. 21, tp. 6, rge. 1, W 5th mer. (49 $29^{\prime} \mathrm{N}$ Lat, $114^{\circ} 03^{\prime} 30^{\prime \prime} \mathrm{W}$ Long). Sec. shows $55 \mathrm{ft}$ eolian sand overlying, successively, up to $90 \mathrm{ft}$ alluvium and as much as $110 \mathrm{ft}$ outwash. Coll. 1967 by A. M. Stalker.

GSC-898. Castle River, shells (II)

$1790 \pm 140$

Terrestrial-gastropod shells (Oreohelix strigosa Gould, id. by A. M. Clarke, Jr., Natl. Mus. of Canada) from topmost buried soil, directly underlying eolian sand. Sample from near center of 'Mountain Mill Bluff' and ca. 220 ft above Castle R., alt ca. 4000 ft.

GSC-901. Castle River, charcoal (II)

$2490 \pm 180$

Charcoal from firebands, contained in alluvium near $\mathrm{E}$ end 'Mountain Mill Bluff'. Ca. $12 \mathrm{ft}$ above lowest and best-developed (of 3) major buried soil in sec., $15 \mathrm{ft}$ above basal outwash, and $60 \mathrm{ft}$ above Castle R., alt ca. $3830 \mathrm{ft}$.

General Comment (A.M.S.): GSC-901 gives approx. age for deposition of alluvium, which probably resulted from glacier advances upvalley 
(Stalker, 1969b). It indicates underlying soil developed during Climatic Optimum, for basal outwash has yielded dates of $6150 \pm 140$ (GSC-447, bison jaw), $6100 \pm 180$ (GSC-490, bison teeth; both in Radiocarbon, 1967, v. 9, p. 169), and $6340 \pm 140$ (GSC-705, bison bone; Radiocarbon, 1968 , v. 10, p. 221). GSC-901 came from same beds as GSC-741 (3380 \pm 170 , Oreohelix strigosa shells) and GSC-743 (2680 \pm 140 , charcoal; both in Radiocarbon, 1968, v. 10, p. 221); its closer agreement with GSC-743 than with GSC-741 suggests that terrestrial gastropods of area can date several hundred yr too old. GSC-898 date is maximum for start of last episode of dune development. Because terrestrial-gastropod shells were used, date also may be several hundred yr too old. Only outermost $10 \%$ of GSC-898 removed due to small sample size (11.9 g). Both samples mixed with dead gas for counting. GSC-898 based on one 3-day count.

\section{Cochrane Terrace series, Alberta (II)}

Bones from middle terrace of 3 postglacial terraces of Bow River near Cochrane, Alberta. Surface of terrace lies ca. $75 \mathrm{ft}$ above river and ca. $25 \mathrm{ft}$ below highest terrace. Samples coll. from cross-bedded, sandy alluvium ca. $7 \mathrm{ft}$ below terrace surface. Fauna includes Bison bison occidentalis, Equus conversidens, Ovis canadensis, and Cervus canadensis (id. by C. S. Churcher, Univ. of Toronto; cf. Churcher, 1968).

\section{GSC-988. Griffin Gravel Pit, Cochrane (II)}

$5670 \pm 150$

Bone from E. Griffin Gravel Pit, ca. 0.5 mi ESE of Cochrane, Alberta, in $\mathrm{NE} 1 / 4$ sec. 35 , tp. 25 , rge $4, \mathrm{~W}$ th mer. $\left(51^{\circ} 10^{\prime} 40^{\prime \prime} \mathrm{N}\right.$ Lat, $114^{\circ} 27^{\prime}$ 10" W Long). Coll. 1965, 1966, 1967 by C. S. Churcher and A. M. Stalker.

\section{GSC-989. Clarke Gravel Pit, Cochrane (II)}

$11,100 \pm 160$

Bone from A. Clarke and Sons' Gravel Pit, ca. $0.3 \mathrm{mi}$ SE of Cochrane, Alberta, in NW $1 / 4$ sec. 35 , tp. 25 , rge. 4 , W 5 th mer. $\left(51^{\circ} 10^{\prime} 40^{\prime \prime} \mathrm{N}\right.$ Lat, $114^{\circ} 27^{\prime} 30^{\prime \prime} \mathrm{W}$ Long). Coll. 1965, 1966, 1967 by G. Clarke and C. Clarke, both of Cochrane, C. S. Churcher, and A. M. Stalker.

General Comment (A.M.S.): GSC-989 agrees closely with GSC-613 (11,370 \pm 170, Radiocarbon, 1967, v. 9, p. 170) from same pit (Stalker, 1968). GSC-988 is much younger than previous date from same pit (GSC-612, $10,760 \pm 160$ (Radiocarbon, 1967, v. 9, p. 169-170); sample may have been contaminated by inclusion of modern bones or during preparation of bones for identification. $\mathrm{NaOH}$-leach omitted from pretreatment of GSC-988; sample mixed with dead gas for counting; date based on one 4-day count.

\section{Warden Rock series, Alberta}

Charcoal and gastropod shells from bedded sands overlying till 70 to $80 \mathrm{ft}$ above Red Deer R. Layer of volcanic ash overlies till and underlies dated samples. Sand appears to be related to main stream, although occurring over a wide range of alt. Warden Rock site is $46 \mathrm{mi}$ WSW of 
Sundre, on N bank of Red Deer R. 1 mi E of Banff Natl. Park Boundary, Alberta (51 42' 50" N Lat, $115^{\circ} 41^{\prime} 30^{\prime \prime}$ W Long). Coll. 1967 by M. J. Chambers, Univ. of Calgary, Calgary.

GSC-894. Warden Rock site, lower charcoal

Charcoal from base of sand, $12 \mathrm{ft}$ depth.

920 B.c.

\section{GSC-906. Warden Rock site, shells}

$$
2510 \pm 180
$$

560 в.C.

$\delta C^{13}=-6.7 \%$

Gastropod shells (Angispira alternata) from sand at 8 to $12 \mathrm{ft}$ depth. No correction applied to date as initial $\mathrm{C}^{14}$ content unknown.

GSC-974. Warden Rock site, upper charcoal

$$
\begin{aligned}
& 1580 \pm 140 \\
& \text { A.D. 370 } \\
& \delta C^{13}=-23.5 \% \text { o }
\end{aligned}
$$

Charcoal from sand at $8 \mathrm{ft}$ depth.

General Comment (W. Blake, Jr.): dates show good internal agreement between shells and charcoal. GSC-974, $1580 \pm 140 \mathrm{yr}$ old, indicates this sec. of Red Deer R. has cut down $75+\mathrm{ft}$ in less than $1500 \mathrm{yr}$, a minimum mean rate of $5 \mathrm{ft} / 100 \mathrm{yr}$. GSC-894 mixed with dead gas for counting. Pretreatment of GSC-906 included leaching of only outer $5 \%$ of shells, because of small sample size $(5.5 \mathrm{~g})$. Sample mixed with dead gas for counting. NaOH-leach omitted from pretreatment of GSC-974. Dates for GSC-906 and GSC-974 each based on one 3-day count.

\section{GSC-1020. Watino, Alberta}

$43,500 \pm 620$

Wood from $2 \mathrm{ft}$ above base of coarsely bedded to massive silt ca. $10 \mathrm{ft}$ thick, $53 \mathrm{ft}$ above Smoky R. and $98 \mathrm{ft}$ below surface, $\mathrm{W}$ bank, ca. 0.5 to $0.75 \mathrm{mi}$ upstream from Watino, Alberta $\left(55^{\circ} 43^{\prime} \mathrm{N}\right.$ Lat, $117^{\circ} 38^{\prime}$ $\mathrm{W}$ Long). Bedrock at river level is overlain, successively, by colluvium and scree, quartzite gravels, sand, and bedded silt and clay. Above wood, peat, and mollusc-bearing unit are interbedded sand, silt and clay (first Shield stones at top of this unit), then glacial gravel and sand overlain by fine sand and silt. Coll. 1968 by J. Westgate, Univ. of Alberta, Edmonton. Comment (J.W.): dated horizon is ca. $65 \mathrm{ft}$ below oldest sediments containing Shield stones, suggesting that Watino area was not glaciated until Late Wisconsin time. Date agrees with GX-1207, >38,000 on wood from same layer, and with I-2516 $(35,500+2300)$ and I-2615 $(35,500+2300)$, on wood from beds 3 and $9 \mathrm{ft}$ higher, respectively, and shows that I-2616 $\left(34,900+\begin{array}{c}+3000 \\ -2000\end{array}\right)$, on wood in gravel $13 \mathrm{ft}$ lower, must be too young. Date based on one 3-day count and one 1-day count in 5-L counter at $4 \mathrm{~atm}$. 


$$
1220 \pm 130
$$

GSC-832. Leviathan Lake, British Columbia, wood A.D. 730

Wood at $5 \mathrm{~cm}$ depth beneath "surface" volcanic ash layer at W edge of Leviathan Lake, $1 \mathrm{mi} \mathrm{E}$ of mouth of Campbell Creek, E side of Kootenay Lake, $3.5 \mathrm{mi} \mathrm{NE}$ of Kaslo, British Columbia $\left(49^{\circ} 57^{\prime} 00^{\prime \prime} \mathrm{N}\right.$ Lat, $116^{\circ} 51^{\prime} 15^{\prime \prime} \mathrm{W}$ Long). Volcanic ash bed (1 cm thick) is beneath $4 \mathrm{~cm}$ peaty turf. Basal peat $(190 \mathrm{~cm}$ depth) is $10,270 \pm 190 \mathrm{yr}$ old (GSC-719; Radiocarbon, 1968, v. 10, p. 223-224; Fulton, 1968). Coll. 1966 by R. J. Fulton. Comment (R.J.F.): date is maximum for overlying volcanic ash bed. Preliminary petrographic study suggests correlation with St. Helens W ash fall (Wilcox, 1965; Crandell et al., 1962). Sample mixed with dead gas for counting. Date based on one 3-day count.

\section{Meadow Creek series, British Columbia (II)}

Peat from road cuts near borrow pit on E side of Meadow Creek, $1.5 \mathrm{mi} \mathrm{W}$ of Duncan Lake Dam and $6 \mathrm{mi} \mathrm{N}$ of Kootenay Lake, British Columbia $\left(50^{\circ} 15^{\prime} \mathrm{N}\right.$ Lat, $116^{\circ} 59^{\prime} \mathrm{W}$ Long). Road cut exposes till overlying interstratified silt and gravel containing peat beds and wood (Fulton, 1968). Coll. 1967 by R. J. Fulton. For other dates in same series see Radiocarbon, 1968, v. 10, p. 224-225.

\section{GSC-1015. Meadow Creek (VIII)}

$42,300 \pm 650$

40,350 в.c.

Woody stems and sphagnum moss, scattered through $40 \mathrm{~cm}$ of silt and fine-grained sand, $1.9 \mathrm{~m}$ below contact with till. Date based on four 1 -day counts in 5 - $\mathrm{L}$ counter at $4 \mathrm{~atm}$.

\section{GSC-1017. Meadow Creek (IX)}

$41,500 \pm 520$

39,550 в.c.

Peat from 2-cm-thick bed in silt, $3 \mathrm{~m}$ below contact with till.

General Comment (R.J.F.): GSC-1015 was ca. $5.5 \mathrm{~m}$ lower in sequence than GSC-740 (43,800 \pm 800; Fulton, 1968; Radiocarbon, 1968, v. 10, p. 224), a wood sample. It was hoped that age of subtill sediments would be extended. Anomalously young date may be due to rootlet penetration of sampled zone after sediment deposition. GSC-1017 was coll. ca. $1.5 \mathrm{~m}$ below GSC-720, peat dated at 42,300 $\pm 700 \mathrm{yr}$ (loc. cit.). Even though statistical errors of dates overlap by ca. 400 radiocarbon yr, GSC1017 appears younger than stratigraphy and other dates from this sec. indicate; cf. GSC-716 (41,800 \pm 600) and GSC-733 (41,900 \pm 600; loc. cit.). Date based on one 1-day and one 3-day count in 5-L counter at $4 \mathrm{~atm}$.

$33,000 \pm 280$

\section{GSC-1008. Balfour Creek, British Columbia 31,050 в.c.}

Charcoal from road cut near Balfour Creek, N side of Columbia R. 5 mi W of Castlegar, British Columbia $\left(49^{\circ} 21^{\prime} 00^{\prime \prime} \mathrm{N}\right.$ Lat, $117^{\circ} 44^{\prime} 50^{\prime \prime}$ W Long). Charcoal from $50 \mathrm{~cm}$ of oxidized fine-grained sand interpreted as "A" horizon of paleosol, overlain, successively, by $2 \mathrm{~m}$ gravel and sand, $2 \mathrm{~m}$ till, and $2 \mathrm{~m}$ gravel. Coll. 1967 by R. J. Fulton. Comment (R.J.F.): 
date confirms field interpretation that sand unit was deposited during Olympia Interglaciation (cf. Armstrong et al., 1965; Fulton, 1968). Date is based on one 1-day and one 3-day count in 5-L counter at $4 \mathrm{~atm}$.

\section{GSC-855. Sheep Lake, British Columbia}

$10,000 \pm 150$

Peat from base of bog deposit on Blueberry Creek-Big Sheep Creek divide, $16 \mathrm{mi}$ WSW of Castlegar, British Columbia $\left(49^{\circ} 14^{\prime} 40^{\prime \prime} \mathrm{N}\right.$ Lat, $117^{\circ} 48^{\prime} 50^{\prime \prime}$ W Long) at alt ca. $4350 \mathrm{ft}$. Bog deposit consists of $330 \mathrm{~cm}$ peat with $1-\mathrm{cm}$-thick volcanic ash bed at $35 \mathrm{~cm}$ depth and 18 -cm-thick volcanic ash bed at $235 \mathrm{~cm}$ depth. Sample from 320 to $330 \mathrm{~cm}$ depth. Coll. 1967 by R. J. Fulton with Davis sampler. Comment (R.J.F.): date is minimum for deglaciation of Rossland Range of Monashee Mts. $\mathrm{NaOH}-\mathrm{leach}$ omitted from sample pretreatment.

\section{Twobit Creek series, British Columbia}

Bog deposit $1 \mathrm{mi} \mathrm{E}$ of Lower Arrow Lake, 1.5 mi SE of mouth of Twobit Creek, $7 \mathrm{mi}$ NNW of mouth of Deer Creek $\left(49^{\circ} 30^{\prime} 30^{\prime \prime} \mathrm{N}\right.$ Lat, $118^{\circ} 05^{\prime} 20^{\prime \prime} \mathrm{W}$ Long) at alt. ca. $2400 \mathrm{ft}$. Bog deposit consists of 109 $\mathrm{cm}$ peat and fibrous muck overlying $114 \mathrm{~cm}$ marl (in part peaty). A $3-\mathrm{cm}$ thick volcanic ash bed is present at 25 to $28 \mathrm{~cm}$ depth; an 8 -cm-thick volcanic ash bed at 96 to $104 \mathrm{~cm}$ depth. Coll. 1967 by R. J. Fulton with Davis sampler.

GSC-875. Twobit Creek, peaty marl

$8310 \pm 150$

Peaty marl (124 to $134 \mathrm{~cm}$ depth) from below fibrous muck-marl contact. Two determinations were made; cf. Table 5, this list:

$$
\begin{array}{cr}
\begin{array}{l}
\text { inorganic portion (marl) (one 3-day count) } \\
\text { organic portion, left after sample dissolved in }
\end{array} & 8540 \pm 140 \\
\mathrm{H}_{3} \mathrm{PO}_{4} \text { (one 3-day count) } & 8310 \pm 150 \\
& \mathbf{1 1 , 0 0 0} \pm \mathbf{1 8 0} \\
\text { GSC-909. Twobit Creek, basal marl } & \mathbf{9 0 5 0} \text { B.c. }
\end{array}
$$

Marl from base of bog deposit (230 to $238 \mathrm{~cm}$ depth). Blue clay, sand, and silt occur at 238 to $250 \mathrm{~cm}$ depth.

General Comment (R.J.F.): ages of both portions of GSC-875 were determined to establish degree of correspondence between peat and marl dates for this area. Organic part might be expected to give slightly younger date than inorganic, as dated material might contain rootlets from overlying fibrous muck, but two dates agree closely, unlike others reported in this list for New Brunswick (GSC-657, GSC-662, and GSC675). GSC-909 is minimum date for deglaciation of Valkyr Range of Selkirk Mts. Date is somewhat older than other bog bottom determinations from this general area; cf. GSC-719 (10,270 \pm 190 ; Radiocarbon, 1968 , v. 10, p. 223-224; Fulton, 1968); GSC-855 (10,000 \pm 150$)$ and GSC$905(10,200 \pm 190)$, both in this list. 


\section{GSC-961. Fauquier, British Columbia}

Wood from test hole drilled in bottom of Lower Arrow Lake at Fauquier, $42 \mathrm{mi} \mathrm{NNW}$ of Castlegar, British Columbia $\left(49^{\circ} 52^{\prime} 20^{\prime \prime} \mathrm{N}\right.$ Lat, $118^{\circ} 05^{\prime} 40^{\prime \prime} \mathrm{W}$ Long). Drill hole penetrated $50 \mathrm{ft}$ gravelly sand overlying $150 \mathrm{ft}$ sand containing silt and clay beds and traces of organic materials. Wood obtained with split tube sampler from depth $150 \mathrm{ft}$ in cased hole. Coll. 1966 by H. G. Gilchrist; subm. by W. H. Mathews, Univ. of British Columbia, Vancouver. Comment (R.J.F.): date indicates sediments to depth of at least $150 \mathrm{ft}$ are postglacial.

\section{GSC-923. Lusk Lake, British Columbia}

$9280 \pm 160$ 7330 B.c.

Basal peat at $560 \mathrm{~cm}$ depth from bog, $0.5 \mathrm{mi} \mathrm{N}$ of Lusk Lake, 18 $\mathrm{mi} \mathrm{E}$ of Enderby and $34 \mathrm{mi} \mathrm{N}$ of Lumby, British Columbia $\left(50^{\circ} 36^{\prime}\right.$ $30^{\prime \prime} \mathrm{N}$ Lat, $118^{\circ} 43^{\prime} 30^{\prime \prime} \mathrm{W}$ Long). Basal peat overlain by intercalated marl and peat containing volcanic ash at $190 \mathrm{~cm}$ depth, and underlain by lacustrine silty clay. Coll. 1968 by G. W. Smith (Ohio State Univ., Columbus; now at Ohio Univ., Athens, Ohio) with Hiller peat sampler. Comment (G.W.S.): date is minimum for deglaciation. NaOH-leach omitted from sample pretreatment. Date based on one 4-day count.

\section{GSC-905. Bear Valley, British Columbia}

$10,200 \pm 190$ 8250 в.c.

Fibrous plant material within lacustrine silty clay near base of bog, surface alt ca. $2650 \mathrm{ft}, 8.5 \mathrm{mi} \mathrm{W}$ of Lumby, British Columbia $\left(50^{\circ} 15^{\prime}\right.$ $\mathrm{N}$ Lat, $118^{\circ} 47^{\prime} \mathrm{W}$ Long). Silty clay, which extends to $400+\mathrm{cm}$ depth, is overlain by intercalated marl and peat containing volcanic ash at $42 \mathrm{~cm}$ depth. Coll. 1968 by G. W. Smith with Davis sampler at $260 \mathrm{~cm}$ depth. Comment (G.W.S.): date is minimum for deglaciation. $\mathrm{NaOH}$ leach omitted from sample pretreatment. Sample mixed with dead gas for counting. Date based on one 3-day count.

\section{GSC-913. Bessette Creek, British Columbia}

$19,100 \pm 240$

17,150 в.c.

Plant detritus and peat within lacustrine sediments from stream cut on S bank of Bessette Creek, ca. 5 mi NW of Lumby, British Columbia $\left(50^{\circ} 18^{\prime} \mathrm{N}\right.$ Lat, $118^{\circ} 5 \mathrm{l}^{\prime} \mathrm{W}$ Long). Sampled horizon occurs ca. $65 \mathrm{ft}$ above stream at top of undetermined thickness of organic silt and sand overlain, successively by $60 \mathrm{ft}$ laminated silt and $70 \mathrm{ft}$ sand and gravel capped by till and veneer of lacustrine silt. Coll. 1968 by G. W. Smith. Comments (G.W.S.): date is maximum for last (Fraser) glacial advance; cf. GSC-194 (20,230 \pm 270; Radiocarbon, 1965, v. 7, p. 33); (R.J.F.): fibrous nature of dated material makes it impossible to tell if sample was contaminated by rootlets of modern plants rooted in sampled unit. $\mathrm{NaOH}-\mathrm{leach}$ omitted from sample pretreatment. 


\section{GSC-1004. Lavington, British Columbia}

Fibrous organic material mixed with sand and silt, from base of bog, 540 to $550 \mathrm{~cm}$ depth, $\mathrm{N}$ side of Coldstream Creek valley $11 \mathrm{mi} \mathrm{E}$ of Vernon, near Lavington, British Columbia $\left(50^{\circ} 14^{\prime} 10^{\prime \prime} \mathrm{N}\right.$ Lat, $119^{\circ}$ $01^{\prime} 30^{\prime \prime}$ W Long) at alt ca. $1700 \mathrm{ft}$. Deposit consists of $550 \mathrm{~cm}$ mucky peat, with $10 \mathrm{~cm}$-thick volcanic ash (Mazama?) layer at 360 to $370 \mathrm{~cm}$, overlying $100 \mathrm{~cm}$ sandy silt and clay containing thin beds of fibrous organic material. Coll. 1966 with Hiller peat sampler by R. J. Fulton. Comment (R.J.F.): Coldstream Creek valley was spillway for glacial lakes occupying Shuswap R. valley E of Lumby. Date is minimum for deglaciation and for last use of spillway. Sandy silt and other poorly sorted and poorly stratified sediments in lower part of sequence are fan deposits; date approximates end of significant fan deposition more closely than beginning of post-spillway sedimentation; cf. GSC-923 (9280 \pm 160$)$ and GSC-905 $(10,200 \pm 190)$, both basal bog dates near Lumby (this list). $\mathrm{NaOH}$-leach omitted from sample pretreatment. Date based on one 4-day count.

\section{Rutland series, British Columbia}

Wood from holes drilled near Rutland on E side of Okanagan Lake. Coll. 1964 by E. Livingston, Water Investigations Branch, Dept. of Lands, Forests, and Water Resources, Victoria.

GSC-563. Black Mountain No. 1

$30,180 \pm 530$

Wood from $190 \mathrm{ft}$ depth in cable-tool hole $6 \mathrm{mi}$ ENE of bridge at Kelowna $\left(49^{\circ} 54^{\prime} 45^{\prime \prime} \mathrm{N}\right.$ Lat, $119^{\circ} 20^{\prime} 30^{\prime \prime} \mathrm{W}$ Long). Wood from 100 -ftthick sand-silt unit overlain by $50 \mathrm{ft}$ till and $95 \mathrm{ft}$ glacio-lacustrine silt.

\section{GSC-1005. Rutland No. 1}

$30,700 \pm 1090$

28,750 в.c.

Wood from $299 \mathrm{ft}$ depth in cable-tool hole $4 \mathrm{mi}$ ENE of bridge at

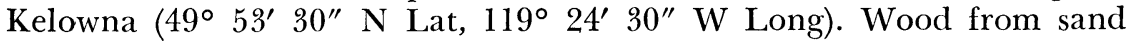
and silt at least $150 \mathrm{ft}$ thick. This plant bearing unit is overlain by thick glacio-lacustrine silt.

General Comment (E.L.): samples of wood are from silty sand containing plant remains, widespread in Okanagan Valley. Several deep test holes indicate that these beds may be as thick as $900 \mathrm{ft}$. Drilling shows that unit is only locally overlain by till (as in Black Mountain No. 1 hole). Dates indicate that silt sand unit was deposited during Olympia Interglaciation (cf. Armstrong et al., 1965; Fulton, 1968). GSC-1005 mixed with dead gas for counting. Each date based on one 3-day count.

\section{GSC-763. MacKenzie Ave., Victoria, $\quad 12,720 \pm 160$ British Columbia 10,770 B.c.}

Whole shells (Hiatella arctica) from shell bed overlying gray silty clay and overlain by peat, exposed in ditch leading to culvert under 
MacKenzie Ave. a few hundred ft E of Quadra St., Victoria, British Columbia (48 $27^{\circ} 39^{\prime \prime} \mathrm{N}$ Lat, $123^{\circ} 26^{\prime} 36^{\prime \prime} \mathrm{W}$ Long). Coll. 1962 and subm. by H. W. Nasmith, R. C. Thurber \& Assoc., Ltd., Victoria, during drilling. Comment (H.W.N.): shell bed at alt $85 \mathrm{ft}$ (geodetic) dates from latest marine submergence; age agrees with other dates from region (cf. Comment for GSC-945, this list).

\section{Rithets Bog series, British Columbia}

Gyttja samples from Rithets Bog, junction of Royal Oak Ave. and Patricia Hwy., Saanich Peninsula, Vancouver I., British Columbia $\left(48^{\circ}\right.$ $27^{\prime} \mathrm{N}$ Lat, $123^{\circ}$ 29' W Long). Coll. 1967 with Hiller peat borer by J. T. Fyles, B. C. Dept. of Mines and Petroleum Resources and H. W. Nasmith in connection with preparation of display for Provincial Mus., Victoria.

\section{GSC-945. Rithets Bog, basal gyttja}

$11,400 \pm 190$

Gyttja from $9.9 \mathrm{~m}$ depth, ca. 5 to $8 \mathrm{~cm}$ above contact with underlying marine clay.

GSC-963. Rithets Bog, gyttja below ash

$$
\begin{aligned}
& 6390 \pm 160 \\
& 4440 \text { в.с. }
\end{aligned}
$$

Gyttja from $6.6 \mathrm{~m}$ depth below distinctive layer of ash believed to be from Mt. Mazama (Crater Lake), Oregon.

General Comment (H.W.N.): date GSC-945 marks early stage of freshwater deposition following late glacial marine submergence. Pond was isolated from sea when relative sea level fell below alt $50 \mathrm{ft}$. Date agrees with those on marine shells from elsewhere on Saanich Peninsula: GSC246 (12,660 \pm 160 ; Radiocarbon, 1965, v. 7, p. 36) at alt $90 \mathrm{ft}$; GSC-398 $(12,440 \pm 230)$ and GSC-418 (12,750 \pm 170 ; both in Radiocarbon, 1966, v. 8, p. 113), for sea levels at alt $60+\mathrm{ft}$ and ca. $80 \mathrm{ft}$, respectively; and GSC-763 $(12,720 \pm 160$; this list) at alt $85 \mathrm{ft}$. GSC-963 is possibly slightly younger than generally accepted age for Mt. Mazama eruption (6600 B.P., Powers and Wilcox, 1964); cf. GSC-214, (6270 \pm 140; Radiocarbon, 1965, v. 7, p. 33; date on organic muck above ash near Okanagan Lake, B.C.), but date is believed to confirm source of ash in Rithets $\mathrm{Bog}$; $\mathrm{NaOH}$ leach omitted from pretreatment of both samples. GSC-963 mixed with dead gas for counting.

\section{Northern Canada, Mainland}

\section{GSC-781. West Aishihik River, Yukon}

Organic silt from stringer $7 \mathrm{ft}$ below surface in natural exposure in gully, $\mathrm{N}$ side West Aishihik R., Yukon (61 $0.25^{\prime} \mathrm{N}$ Lat, $137^{\circ} 07.6^{\prime}$ W Long). Stringer is at irregular contact of gray-brown silt (above) and permanently frozen gray silt (below). Gray silt was deposited in glacial lake during retreat of ice tongue from West Aishihik Valley; gray-brown silt is probably reworked by colluviation and cryoturbation, contact forming base of active layer. Coll. 1966 by O. L. Hughes. Comment (O.L.H.): date is minimum for drainage of glacial lake in West Aishihik 
Valley. NaOH-leach omitted from sample pretreatment. Sample mixed with dead gas for counting.

\section{Aishihik Lake series, Yukon}

Wood and peat from near Aishihik Lake, Yukon. Coll. 1966 by O. L. Hughes.

\section{GSC-749. Aishihik Lake, peat}

$$
9660 \pm 150
$$

Peat from frozen pond sediments in depression on hummocky moraine belt, at NW corner of unnamed radio towers, $3.6 \mathrm{mi} \mathrm{N}$ of Aishihik Lake $\left(61^{\circ} 40.7^{\prime} \mathrm{N}\right.$ Lat, $137^{\circ} 27.2^{\prime}$ W Long). Discontinuous organic layer (this sample) $0.5 \mathrm{ft}$ thick (in sand) is underlain by blue-gray lacustrine silt and overlain, successively, by $1.3 \mathrm{ft}$ silty clay with abundant molluscs, $3 \mathrm{ft}$ fine sand with molluscs at base and organic stringers at top, $0.5 \mathrm{ft}$ White River Ash, and $0.1 \mathrm{ft}$ surface organic layer.

GSC-755. Aishihik Lake, wood

Wood from $5.1 \mathrm{ft}$ below surface in bluff, $\mathrm{N}$ shore of Aishihik Lake $\left(61^{\circ} 37^{\prime} \mathrm{N}\right.$ Lat, $137^{\circ} 29^{\prime} \mathrm{W}$ Long). Woody layer $0.2 \mathrm{ft}$ thick is underlain by silty clay that grades downward into distinctly varved glacio-lacustrine sediments and is overlain by $2.1 \mathrm{ft}$ silty clay with molluscs, $1.1 \mathrm{ft}$ silt with peat stringers, $0.8 \mathrm{ft}$ silty peat with molluscs, $0.2 \mathrm{ft}$ organic soil with charcoal, $0.6 \mathrm{ft}$ White River Ash, $0.2 \mathrm{ft}$ eolian silt with organic stringers. General Comment (O.L.H.): GSC-749 is minimum for retreat of ice from position marked by moraine belt. GSC-755 is minimum for drainage of glacial lake that occupied basins of Sekulmun and Aishihik Lakes and drained $\mathrm{N}$ to Nisling R.; it is compatible with GSC-749. Each date based on one 3-day count.

\section{GSC-867. Kluane Lake, Yukon}

$340 \pm 130$

Wood from in situ white spruce stump partly imbedded in beach gravel, $6 \mathrm{ft}$ below normal high water level, $\mathrm{S}$ side of Christmas Bay, Kluane Lake, Yukon (61 $03.5^{\prime} \mathrm{N}$ Lat, $138^{\circ} 21^{\prime} \mathrm{W}$ Long). Stump excavated to 18 in. below gravel surface, then cut off with saw; depth to base of stump (i.e., original surface level) unknown but probably $<5 \mathrm{ft}$. Outermost $0.5 \mathrm{~cm}$ (ca. 20 annual rings) used for dating. Coll. 1967 by J. Look and R. Klaubert for O. L. Hughes. Comment (O.L.H.): stumps of drowned spruce forest are common in Christmas Bay and elsewhere in Kluane Lake; according to Bostock $(1952,1969)$ trees were drowned when Neoglacial advance of Kaskawulsh Glacier dammed a S outlet of Kluane Lake via Slims-Kaskawulsh Valley, and forced discharge through present NW outlet (cf. Borns and Goldthwait, 1966; Denton and Stuiver, 1966, 1967; Porter and Denton, 1967). Date based on one 3-day count. 


\section{Silver Creek series, Yukon}

Organic debris including wood, from silt beds in Icefield Outwash II, W side of Silver Creek, Yukon $\left(61^{\circ} 00^{\prime} \mathrm{N}\right.$ Lat, $138^{\circ} 19^{\prime} \mathrm{W}$ Long). Exposures at this locality have been studied in detail by Denton and interpreted by Denton and Stuiver (1967). Coll. 1966 by O. L. Hughes and V. Rampton. Detailed cross sections provided by Denton in advance of publication were used to duplicate as closely as possible samples coll. by Denton that yielded finite "older" dates. Samples were intended to be cross-check with Yale Radiocarbon Lab.

GSC-734. Silver Creek series (I)

Organic debris including wood in silt layer within gravel of Icefield Outwash II; same as Y-1356 (37,700 +1500 ; Denton and Stuiver, 1967).

Comment (J.A.L. and W.B., Jr.): small sample size used (100 g) necessitated dating in 2-L counter, in which finite ages over 35,000 yr are rarely obtained. NaOH-leach omitted from sample pretreatment. Sample mixed with dead gas for counting.

\section{GSC-769. Silver Creek series (II)}

Organic debris including wood in silt layer within gravel of Icefield Outwash II; same as Y-1385 (30,100 \pm 600 ; Denton and Stuiver, 1967). Comment (O.L.H.): agreement with Y-1385 is within stated limits of error. Pretreatment included cold NaOH-leach. Date based on one 3day count.

\section{GSC-895. Bighorn Glacier, Yukon}

A.D. 1780

$170 \pm 140$

Wood chunks and rootlets from within ice-contact stratified material deposited after stagnation and melting of "surged" Bighorn Glacier, Yukon $\left(61^{\circ} 05 \mathrm{~N}\right.$ Lat, $139^{\circ} 05^{\prime} \mathrm{W}$ Long). Organic matter from sand bed at ca. $20 \mathrm{ft}$ depth in $40 \mathrm{ft}$ sec. of freshly exposed coarse material. Coll. 1967 by N. W. Rutter. Comment (N.W.R.): since wood is interpreted as material that lived before "surge", age is maximum for time of "surge" (Rutter, 1969). Sample mixed with dead gas for counting.

\section{GSC-996. Dempster Highway, Yukon, wood}

$$
\begin{aligned}
& 4630 \pm 130 \\
& 2680 \text { B.c. } \\
& \delta C^{13}=-24.9 \% \circ
\end{aligned}
$$

Wood from base of 10 -ft-thick frozen peat layer in roadside exposure, at Mile 102, Dempster Hwy., Yukon (65 $05^{\circ}$ N Lat, $139^{\circ} 30^{\prime}$ W Long). Peat overlies outwash from oldest recognized glaciation in Ogilvie Mts. (Vernon and Hughes, 1966). Coll. 1966 by J. T. Gray, McGill Univ., Montreal. Comment (J.T.G.): date obtained is too young to establish glacial chronology of area. Peat development at site appears to have been recent phenomenon, dependent upon other factors than time of deglaciation. Date based on one 4-day count. 


\section{Wolverine Creek series, Yukon}

Organic clay and wood from $\mathrm{N}$ bank of Wolverine Creek, $0.3 \mathrm{mi}$ downstream from mouth of Lynx Creek, Yukon (61 $31^{\circ} \mathrm{N}$ Lat, $139^{\circ}$ 53.5' W Long). Coll. 1967 by V. N. Rampton.

GSC-919. Wolverine Creek, Yukon (I)

Organic clay overlies $2.5 \mathrm{ft}$ gravel and $10+\mathrm{ft}$ till, and underlies $5 \mathrm{ft}$ clay, $45 \mathrm{ft}$ sand, $80 \mathrm{ft}$ gravel, and $30+\mathrm{ft}$ till.

GSC-962. Wolverine Creek, Yukon (II)

Wood (compressed twigs) from $20 \mathrm{ft}$ deltaic sand overlying, successively, $25 \mathrm{ft}$ sand, $5 \mathrm{ft}$ clay, $2 \mathrm{ft}$ organic clay, $7.5 \mathrm{ft}$ gravel, and $10+$ $\mathrm{ft}$ till, and underlying $80 \mathrm{ft}$ gravel and $30+\mathrm{ft}$ till.

General Comment (V.N.R.): dates indicate that sediments (enclosing organic materials) resulting from damming of valley by glacier advance from $\mathrm{E}$ (which deposited upper till) were laid down more than 40,000 yr ago, (Rampton, 1969), GSC-962 being considered more reliable than GSC-919. NaOH-leach omitted from pretreatment of GSC-919. Date for GSC-962 based on one 5-day count.

GSC-960. O'Brian Creek, Yukon

Peat from near base of $54+\mathrm{ft}$ of organic silt, $\mathrm{E}$ bank of White $\mathrm{R}$. opposite mouth of O'Brian Creek, Yukon $\left(62^{\circ} 38^{\prime} \mathrm{N}\right.$ Lat, $140^{\circ} 0.5^{\prime}$ W Long). Silts overlie $29 \mathrm{ft}$ gravel. Coll. 1967 by V. N. Rampton. Comment (V.N.R.): date is minimum for deposition of underlying gravels which grade to maximum limit of glaciation on White R. (Rampton 1969). NaOH-leach omitted from sample pretreatment. Sample mixed with dead gas for counting.

\section{GSC-1002-2. Bull Creek, Yukon}

Peat from $6 \mathrm{ft}$ organic silts and colluvium on $\mathrm{W}$ bank of Bull Creek, $5 \mathrm{mi}$ upstream from its mouth, Yukon $\left(61^{\circ} 30^{\prime} \mathrm{N}\right.$ Lat, $140^{\circ} 15^{\prime} \mathrm{W}$ Long). Organic silts and colluvium lie along dipping contact between $150 \mathrm{ft}$ gravel above and $10+\mathrm{ft}$ till below. Coll. 1967 by V. N. Rampton. Two determinations were made:

GSC-1002 (one 1-day count in 2-L counter) $>40,000$

GSC-1002-2 (one 3-day count and two 1-day counts in 5 - $\mathrm{L}$ counter at $4 \mathrm{~atm}$

Comment (V.N.R.): underlying till was deposited over 48,000 yr ago.

\section{St. Clare Creek series, Yukon}

Compressed twigs and silty peat from under tills along St. Clare Creek, near Klutlan Glacier, Yukon. Coll. 1966, 1967 by V. N. Rampton.

GSC-799. St. Clare Creek, Yukon (I)

Compressed twigs and peat overlain, successively, by $45 \mathrm{ft}$ silty till and $10 \mathrm{ft}$ sandy till and overlie $25 \mathrm{ft}$ sandy till on $\mathrm{W}$ bank of St. Clare Creek (61 $31^{\prime} \mathrm{N}$ Lat, $140^{\circ} 31^{\prime} \mathrm{W}$ Long). Upper portion of underlying 
till is oxidized. Exposure is within limits of oldest Neoglacial advance of Klutlan Glacier (cf. GSC-751, $1520 \pm 130$, this list).

GSC-924. St. Clare Creek, Yukon (II)

Silty peat from upper part of $3 \mathrm{ft}$ of silty peat on NE bank of St. Clare Creek, $0.2 \mathrm{mi}$ downstream from mouth of Bull Creek $\left(61^{\circ} 32^{\prime}\right.$ $\mathrm{N}$ Lat, $140^{\circ} 23.5^{\prime} \mathrm{W}$ Long). Silty peat is overlain, successively, by $10 \mathrm{ft}$ sand, $6 \mathrm{ft}$ till, and $80 \mathrm{ft}$ alluvium, and overlies $2+\mathrm{ft}$ of till. Coll. 1966, 1967 by V. N. Rampton.

General Comment (V.N.R.): infinite dates do not permit exact ages of overlying tills to be defined, but underlying till was deposited over 39,000 yr ago. $\mathrm{NaOH}$-leach omitted from pretreatment of GSC-924. Dates for GSC-924 and GSC-799 each based on one 3-day count.

\section{Klutlan Glacier series, Yukon}

Forest duff, spruce needles, and wood assoc. with Neoglacial drift near Klutlan Glacier, Yukon. Coll. 1966, 1967 by V. N. Rampton.

GSC-751. Klutlan Glacier, Yukon (I)

$1520 \pm 130$

Wood from midpoint of $50 \mathrm{ft}$ exposure of till, W bank of Count Creek, $1.5 \mathrm{mi}$ upstream from junction with St. Clare Creek $\left(61^{\circ} 33^{\prime} \mathrm{N}\right.$ Lat, $140^{\circ} 31^{\prime}$ W Long).

\section{GSC-929. Klutlan Glacier, Yukon (II)}

$$
\begin{array}{r}
\mathbf{3 4 0} \pm \mathbf{1 3 0} \\
\text { A.D. } 1610 \\
\delta C^{13}=-23.1 \%
\end{array}
$$

Outer portion of spruce log (30 rings from 130-yr-old tree) from below $1 \mathrm{ft}$ of slightly decomposed moss and from above alluvium and till(?), W bank of St. Clare Creek, $5.5 \mathrm{mi}$ upstream from its mouth $\left(61^{\circ}\right.$ $37^{\prime} \mathrm{N}$ Lat, $140^{\circ} 32.5^{\prime} \mathrm{W}$ Long). Wood wet and partly frozen when coll.

\section{GSC-966. Klutlan Glacier, Yukon (III)}

$$
\begin{array}{r}
\mathbf{3 5 0} \pm \mathbf{1 3 0} \\
\text { A.D. } 1600 \\
\delta C^{13}=-25.6 \%
\end{array}
$$

Spruce needles and forest duff from same stratigraphic position and locality as GSC-929.

\section{GSC-912. Klutlan Glacier, Yukon (IV)}

$$
\begin{array}{r}
\mathbf{3 1 0} \pm \mathbf{1 3 0} \\
\text { A.D. } 1640 \\
\delta C^{13}=-23.6 \%
\end{array}
$$

Branches of tilted trees exposed in creek cut; from between 2 tills at exposure within Klutlan Neoglacial moraines $\left(61^{\circ} 38^{\prime} \mathrm{N}\right.$ Lat, $140^{\circ}$ 33' W Long).

General Comment (V.N.R.): GSC-751 may give age of initial Neoglacial advance (Rampton, 1969). No distinction can be made between ages, in radiocarbon yr, obtained for GSC-929, GSC-966, and GSC-912; GSC-929 and GSC-966 are minima for retreat of ice from maximum Neoglacial position, and GSC-912, farther NW, predates a major Neoglacial readvance. GSC-966 mixed with dead gas for counting. 


\section{White River series, Yukon}

Wood and organic silts from exposures downstream from Alaska Hwy. bridge across White R., Yukon. Coll. 1965, 1966 by V. N. Rampton.

\section{GSC-714. White River, Yukon (I)}

$11,000 \pm 160$

Organic silt from base of bog, $\mathrm{W}$ bank of White R., $2.2 \mathrm{mi}$ downstream from Alaska Hwy. bridge (62。 $01^{\prime} \mathrm{N}$ Lat, $140^{\circ} 34^{\prime} \mathrm{W}$ Long); 1.5 $\mathrm{ft}$ organic silt is overlain by $10 \mathrm{ft}$ peat and underlain, successively, by $12 \mathrm{ft}$ gravel and $45 \mathrm{ft}$ till.

\section{GSC-777. White River, Yukon (II)}

$7760 \pm 170$

Wood from base of bog, W bank of White R., $2.3 \mathrm{mi}$ downstream from Alaska Hwy. bridge $\left(62^{\circ} 01^{\prime} \mathrm{N}\right.$ Lat, $140^{\circ} 34^{\prime} \mathrm{W}$ Long). Peat is underlain, successively, by $2 \mathrm{ft}$ till-like material, $47 \mathrm{ft}$ gravel, and $30 \mathrm{ft}$ till.

GSC-552. White River, Yukon (III)

Organic silt and silty peat from $\mathrm{W}$ bank of White R., $1.3 \mathrm{mi}$ downstream from Alaska Hwy. bridge $\left(62^{\circ} 00^{\prime} \mathrm{N}\right.$ Lat, $140^{\circ} 34^{\prime} \mathrm{W}$ Long). Organic silts are from angular unconformity between till and underlying gravels and sands. Till is capped by gravel and peat.

\section{GSC-732. White River, Yukon (IV)}

$48,000 \pm 1300$

Wood from mud-flow debris, $\mathrm{W}$ bank of White R., $1.2 \mathrm{mi}$ downstream from Alaska Hwy. bridge $\left(62^{\circ} 00^{\prime} \mathrm{N}\right.$ Lat, $140^{\circ} 34^{\prime} \mathrm{W}$ Long). Mudflow debris is underlain by $10 \mathrm{ft}$ till whose top $5.5 \mathrm{ft}$ is oxidized and overlain by slump composed of gray drift.

\section{GSC-995. White River, Yukon (V)}

Wood and silty peat from alluvium, W bank of White R., $1.3 \mathrm{mi}$ downstream from Alaska Hwy. bridge $\left(62^{\circ} 00^{\prime} \mathrm{N}\right.$ Lat, $140^{\circ} 34^{\prime} \mathrm{W}$ Long). Alluvium is at river level and is overlain by $100 \mathrm{ft}$ olive gray till containing pods of peat and mud-flow debris in its basal part. Till is capped by gravel and peat.

General Comment (V.N.R.): GSC-714 is minimum for deglaciation. GSC732 is maximum for time of mud-flow, and minimum for underlying till, although possibility of sample contamination cannot be ruled out (Rampton, 1969). NaOH-leach omitted from pretreatment of GSC-552 and GSC-714. Dates for GSC-552 and GSC-732 each based on one 3-day count, the latter in 5-L counter at $4 \mathrm{~atm}$.

\section{GSC-776. Generc River, Yukon}

$9360 \pm 150$

7410 B.C.

Organic silt from base of peat bog overlying $8 \mathrm{ft}$ till and $25 \mathrm{ft}$ gravel, $\mathrm{W}$ bank of Generc R., $1.5 \mathrm{mi}$ upstream from mouth of unnamed small creek, Yukon ( $61^{\circ} 42.5^{\prime} \mathrm{N}$ Lat, $140^{\circ} 38^{\prime} \mathrm{W}$ Long). Coll. 1966 by V. N. Rampton. Comment (V.N.R.): date is minimum for deglaciation of locality. $\mathrm{NaOH}-$ leach omitted from sample pretreatment. 
White River ash series, Yukon (II)

Wood and forest duff from below $\mathrm{E}$ lobe of White R. volcanic ash which blankets much of SW Yukon (cf. Bostock, 1952; Berger, 1960; Lerbekmo et al., 1968; 1969). Coll. 1966, 1967 by V. N. Rampton.

\section{GSC-748. Little Boundary Creek, Yukon$$
\text { A.D. } 740
$$$$
\delta C^{13}=-21.9 \%
$$

$$
1210 \pm 130
$$

Outer portion of partially exhumed stump at upstream edge of island in channel of Little Boundary Creek, $11 \mathrm{mi}$ from its mouth $\left(61^{\circ} 38^{\prime} \mathrm{N}\right.$ Lat, $140^{\circ} 55^{\prime} \mathrm{W}$ Long); $2 \mathrm{ft}$ lapilli overlie tree roots and soil.

\section{GSC-934. Big Boundary Creek, Yukon (I) \\ A.D. 670
$\delta C^{13}=-24.0 \%$}

Wood and forest duff from below $5 \mathrm{ft}$ lapilli, W bank of Big Boundary Creek, $4.5 \mathrm{mi}$ downstream from Natazhat Glacier $\left(61^{\circ} 37^{\prime}\right.$ $\mathrm{N}$ Lat, $140^{\circ} 49^{\prime} \mathrm{W}$ Long).

\section{GSC-1000. Big Boundary Creek, Yukon (II)}

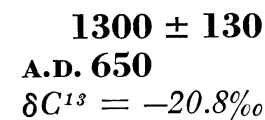

Outer 40 rings of stump protruding through thick blanket of lapilli on upland between Big Boundary Creek and Brooke Creek $\left(61^{\circ} 38^{\prime} \mathrm{N}\right.$ Lat, $140^{\circ} 46^{\prime} \mathrm{W}$ Long).

General Comment (V.N.R.): dates are similar to dates of $1200 \pm 140$ (GSC-408) and $1240 \pm 130$ (GSC-343, both in Radiocarbon, 1968, v. 10, p. 229-230), obtained on material below $E$ lobe of White $R$. ash both N and S of present series; cf. also Fernald, 1962; Stuiver et al., 1964. Date for GSC-1000 based on one 3-day count.

GSC-959. Niggerhead Mountain, Yukon $>\mathbf{3 8 , 0 0 0}$

Peat and organic silt from bank at edge of small lake $\mathrm{N}$ of Niggerhead Mt. and $1.3 \mathrm{mi} \mathrm{W}$ of Alaska Hwy. Mile 1196.3, Yukon $\left(62^{\circ} 18.5^{\prime}\right.$ $\mathrm{N}$ Lat, $140^{\circ} 50^{\prime} \mathrm{W}$ Long). Dated material from near top of $2 \mathrm{ft}$ unit containing ice wedge cast. Unit overlies silt containing peaty layers and is overlain, successively, by peat, gray silt, and turf. Coll. 1967 by V. N. Rampton. Comment (V.N.R.): it was hoped to obtain maximum age for formation of ice wedge and deposition of gray silt (loess); date indicates that enclosing and underlying silts were deposited over 38,000 yr ago. $\mathrm{NaOH}-\mathrm{leach}$ omitted from sample pretreatment. Sample mixed with dead gas for counting. Date based on one 3-day count.

Natazhat Glacier series, Yukon

Wood and peat from below Neoglacial drift, near Natazhat Glacier, Yukon. Coll. 1966, 1967 by V. N. Rampton.

GSC-766. Natazhat Glacier, Yukon (I)

$480 \pm 130$

Peat beneath till of Natazhat Glacier near its Neoglacial terminal 
position ( $61^{\circ} 36^{\prime} \mathrm{N}$ Lat, $140^{\circ} 54^{\prime} \mathrm{W}$ Long). Sample (frozen) coll. at 3.5 $\mathrm{ft}$ depth at headwaters of Little Boundary Creek.

\section{GSC-933. Natazhat Glacier, Yukon (II)}

$$
\begin{array}{r}
\mathbf{3 2 8 0} \pm \mathbf{1 3 0} \\
\mathbf{1 3 3 0} \text { B.C. } \\
\delta C^{13}=-23.0 \% 0
\end{array}
$$

Outer 28 rings of $\log , 30 \mathrm{ft}$ below top of $40 \mathrm{ft}$ till exposure on $\mathrm{W}$ bank of Little Boundary Creek, $0.3 \mathrm{mi}$ downstream from its source $\left(61^{\circ}\right.$ $36^{\prime} \mathrm{N}$ Lat, $140^{\circ} 55^{\prime} \mathrm{W}$ Long).

\section{GSC-1003. Natazhat Glacier, Yukon}

(III)

$$
\begin{gathered}
\mathbf{3 3 0 0} \pm \mathbf{1 3 0} \\
\mathbf{1 3 5 0} \text { B.c. } \\
\delta C^{13}=-23.4 \% \text { o }
\end{gathered}
$$
above.

Log, $28 \mathrm{ft}$ below top of $40 \mathrm{ft}$ till exposure; location as for GSC-933,

General Comment (V.N.R.): GSC-766 is maximum for greatest Neoglacial extent of Natazhat Glacier; GSC-933 and GSC-1003 date an earlier Neoglacial advance (Rampton, 1969; cf. Porter and Denton, 1967). Date for GSC-933 based on one 3-day count.

\section{GSC-932. Cache Creek, Yukon}

$6500 \pm 140$

Peat from lower part of $2.5 \mathrm{ft}$ of silty sand, W bank of White $\mathrm{R}$. $0.5 \mathrm{mi}$ downstream from mouth of Cache Creek, Yukon $\left(61^{\circ} 45^{\prime} \mathrm{N}\right.$ Lat, $140^{\circ} 56^{\prime} \mathrm{W}$ Long). Silty sand overlies, successively, $25 \mathrm{ft}$ gravel, $2.5 \mathrm{ft}$ silt, $15 \mathrm{ft}$ gravel, and $5 \mathrm{ft}$ till, and underlies $5 \mathrm{ft}$ gravel and $32 \mathrm{ft}$ poorly exposed sands, silts, and peat. Coll. 1967 by V. N. Rampton. Comment (V.N.R.): date is minimum for deglaciation of region; cf. GSC-714 $(11,000 \pm 160)$ and GSC-777 (7760 \pm 170 ; both in this list). NaOHleach omitted from sample pretreatment.

\section{B.C. $\delta C^{13}=-23.4 \%$}

Wood (Picea, sp., id. by R. J. Mott) from sand exposed in excavation behind school, Fort Resolution, Northwest Territories $\left(61^{\circ} 10^{\prime} \mathrm{N}\right.$ Lat, $113^{\circ} 40^{\prime} \mathrm{W}$ Long), depth ca. $7 \mathrm{ft}$; ca. $1 \mathrm{ft}$ above Great Slave Lake (alt 513 ft, 1967). Coll. 1967 by W. B. Kudelik, Fort Resolution. Comment (B. G. Craig): sample, from alluvial plain along Slave R. (Craig, 1965a); together with S-268 $(2725 \pm 115)$ and S-269 $(2215 \pm 95$; both in Radiocarbon, 1968, v. 10, p. 371) indicates that relative level of Great Slave Lake had fallen from maximum (ca. $900 \mathrm{ft}$ ) at Glacial Lake McConnell level to its present level by 2300 to 2700 B.P. Date based on one 4-day count.

\section{GSC-1016. Duffy Lake, Northwest Territories \\ $6570 \pm 140$}

Whole shells and fragments (Hiatella arctica) from frost boil in marine silt, alt ca. $400 \mathrm{ft}$, ca. $150 \mathrm{ft}$ below marine limit, $1 \mathrm{mi} \mathrm{NE}$ of Duffy Lake, Northwest Territories (62 $49^{\prime}$ N Lat, $94^{\circ} 48^{\prime}$ W Long). Coll. 1967 
by A. Davidson for B. G. Craig. Comment (B.G.G.): shells are highest coll. in SE Dist. of Keewatin. Date was expected to approximate more closely time of deglaciation and inundation by Tyrrell Sea of NW coast of Hudson Bay than only previous date $(6975 \pm 250, \mathrm{I}(\mathrm{GSC})-8$; shells at alt 210 ft; Lee, 1959; Radiocarbon, 1961, v. 3, p. 50-51). Slightly younger age of present sample indicates that it relates to slightly later stand of Tyrrell Sea than I(GSC)-8. Date based on three 1-day counts.

\section{Northern Canada, Arctic Archipelago}

\section{GSC-911. Henry Kater Peninsula, Baffin Island}

Pelecypod shell fragments (Mya truncata, Astarte striata, and $A$. borealis) from stratified silt and sand, NE coast of Henry Kater Peninsula, Baffin I., Northwest Territories $\left(69^{\circ} 26^{\prime} \mathrm{N}\right.$ Lat, $67^{\circ} 02^{\prime} \mathrm{W}$ Long), at alt $48 \mathrm{ft}, 12 \mathrm{ft}$ below surface. Shells, fragmentary and worn, were assoc. with well-rounded stones, suggesting deposition in beach environment. Coll. site slightly above highest obvious postglacial marine beach features. Coll. 1967 by C. A. M. King, Univ. of Nottingham, Nottingham, England. Comments (C.A.M.K.): age of shells indicates that sea level must have been at least $60 \mathrm{ft}$ higher, relative to land, during an interglacial or interstadial; (W.B.,Jr.): possibility that "old" shells have been redeposited in postglacial feature is not excluded. Sample mixed with dead gas for counting. Date based on one 3-day count.

\section{GSC-991. 'Truelove Inlet', Devon Island}

$8270 \pm 150$ 6320 B.c.

Whalebone from skull imbedded in yellow silty sand, at foot of escarpment $2.5 \mathrm{mi} \mathrm{N}$ of head of 'Truelove Inlet' and $3 \mathrm{mi} \mathrm{E}$ of Arctic Inst. of North America's Base Camp, Devon I., Northwest Territories (75 $40^{\prime} \mathrm{N}$ Lat, $84^{\circ} 23^{\prime} \mathrm{W}$ Long). Skull, lower portion in permafrost, at alt $123 \mathrm{ft}$; marine limit in area at ca. $240 \mathrm{ft}$. Coll. 1967 by W. Barr, McGill Univ., Montreal, now at Univ. of Saskatchewan, Saskatoon. Comment (W.B.): date is reasonable in view of date on marine shells nearer marine limit (Y-1299, $9360 \pm 160$, alt $196 \mathrm{ft}$; cf. Müller and Barr, 1966). Whalebone date is probably more reliable as indicator of contemporary sea level. Both dates uncorrected for any $\mathrm{C}^{14}$ deficiency in Arctic sea water. Date based on one 3-day count.

\section{GSC-891. Ice-cap margin, Ellesmere Island}

$120 \pm 130$

Moss (Rhacomitrium lanuginosum [Hedw.] Brid., id. by G. R. Brassard, Univ. of Ottawa, Ottawa), adjacent to NW margin of main icecap in SW Ellesmere I., Northwest Territories $\left(76^{\circ} 58.5^{\prime} \mathrm{N}\right.$ Lat, $86^{\circ} 14^{\prime}$ W Long), at alt ca. $2400 \mathrm{ft}$. Frozen sample coll. at 3 to 5 in. depth beneath mixed till and outwash, and exposed in rivulet flowing parallel to edge of ice lobe, $15 \mathrm{ft}$ away. Coll. 1967 by W. Blake, Jr. Comment (W.B., Jr.): geomorphic and botanical evidence indicate that moss, a species generally found covering large areas of dry acid ground, and common in vicinity, grew when ice lobe was diminished in size. Moss was killed when ice ad- 
vanced to or beyond present position; in latter case slight retreat of margin has occurred recently, re-exposing moss. Sample mixed with dead gas for counting. Date based on one 4-day count.

\section{GSC-1025. Ward Hunt Island, Ellesmere Island}

$4510 \pm 150$

2560 B.c.

$\delta C^{13}=+1.5 \%$

Pelecypod shells from surface of ice grounded below sea level between $\mathrm{E}$ end of Ward Hunt I. and ice shelf, Ellesmere I., Northwest Territories ( $83^{\circ} 05^{\prime} \mathrm{N}$ Lat, $73^{\circ} 52^{\prime} \mathrm{W}$ Long), at alt 1 to $2 \mathrm{ft}$. Coll. 1968 by G. Hattersley-Smith, Defence Research Bd., Ottawa. Comment (G.H-S.): shells probably picked up from sea bottom by freezing in shallow water, then gradually elev. to ice surface through ablation and further bottom freezing. Date is compatible with other evidence that Ward Hunt Ice Shelf has existed for not more than ca. $3000 \mathrm{yr}$ (cf. Crary et al., 1955; Crary, 1960; Christie, 1967). Dated in 2-L counter at 1 atm.

GSC-637. White Glacier moraine, Axel Heiberg Island $370 \pm 130$ A.D. 1580

Roots and twigs in silt and fine sand beneath till of end moraine, in front of White Glacier, Axel Heiberg I., Northwest Territories $\left(79^{\circ}\right.$ $25.5^{\prime} \mathrm{N}$ Lat, $90^{\circ} 36.7^{\prime} \mathrm{W}$ Long). Moraine above sample is itself overlain by present end moraine of White Glacier. Sample is from interface between horizontally-bedded gravel and till, and is ca. $80 \mathrm{~m} \mathrm{~S}$ of White Glacier. Coll. 1966 by F. Müller and D. Terroux, McGill Univ., Montreal. Comment (F.M.): date agrees with B-464 (240 \pm 100 ; Müller, 1963), on proximal side of older moraine overlying GSC-637 and at interface between gravel and till of present moraine. For dates on organic material in outwash in front of White Glacier moraines see Hegg (1961), Gfeller and Oeschger (1963), and Müller (1963). Date based on one 3day count.

\section{GSC-432. 'Rens Lake', Axel Heiberg Island, 230 ft 12,230 в.c.

$$
\begin{aligned}
& 14,180 \pm 180 \\
& 12,230 \text { B.C. }
\end{aligned}
$$

Pelecypod shells (Hiatella arctica) from surface of patterned ground ca. $1.9 \mathrm{mi}$ NE of 'Rens Lake', Axel Heiberg I., Northwest Territories $\left(81^{\circ} 05.5^{\prime} \mathrm{N}\right.$ Lat, $91^{\circ} 55.5^{\prime} \mathrm{W}$ Long), at alt ca. 213 to $230 \mathrm{ft}$. Site is ca. $131 \mathrm{ft}$ above 'Rens Lake' at $\mathrm{N}$ end of hill with alt ca. $295 \mathrm{ft}$. Coll. 1961 by F. Müller. Comment (F.M.): although sample not coll. at.marine limit, date is older than expected; cf. GSC-167 (8250 \pm 140; Müller, 1963; Radiocarbon, 1965 , v. 7, p. 42), date on shells at ca. $100 \mathrm{ft}$ nearby. Possibly postglacial shells have been mixed with older ones by glacier movement. Outermost $30 \%$ of shell removed prior to dating.

Date lists:

Bern III

GSC I

GSC II

GSC IV

GSC V

\section{REFFRENCFS}

\author{
Gfeller and Oeschger, 1963 \\ Dyck and Fyles, 1962 \\ Dyck and Fyles, 1963 \\ Dyck, Fyles, and Blake, 1965 \\ Dyck, Lowdon, Fyles, and Blake, 1966
}


GSC VI

GSC VII

GSC VIII

Isotopes I

Lamont VII

Saskatchewan V

UCLA V

Lowdon, Fyles, and Blake, 1967

Lowdon and Blake, 1968

Lowdon, Wilmeth, and Blake, 1969

Walton, Trautman, and Friend, 1961

Olson and Broecker, 1961

McCallum and Wittenberg, 1968

Berger and Libby, 1966

Armstrong, J. E., Crandell, D. R., Easterbrook, D. J., and Noble, J. B., 1965, Late Pleistocene stratigraphy and chronology in southwestern British Columbia and northwestern Washington: Geol. Soc. America Bull., v. 76, p. 321-330.

Berger, A. R., 1960, On a recent volcanic ash deposit, Yukon Territory: Geol. Assoc. Canada Proc., v. 12, p. 117-118.

Berger, Rainer and Libby, W. F., 1966, UCLA radiocarbon dates V: Radiocarbon. v. 8, p. $467-497$.

Borns, H. W., Jr., 1967, Field trip guide, Machias, Maine: Friends of the Pleistocene 30th Annual Reunion, May 20-21, 18 p.

Borns, H. W., Jr. and Goldthwait, R. P., 1966, Late-Pleistocene fluctuations of Kaskawulsh Giacier, southwestern Yukon Territory, Canada: Am. Jour. Sci., v. 264, p. 600-619.

Bostock, H. S., 1952, Geology of northwest Shakwak Valley, Yukon Territory: Canada, Geol. Survey Mem. 267, $54 \mathrm{p}$.

1969, Kluane Lake, Yukon Territory; its drainage and allied problems (115G, and 115FE): Canada, Geol. Survey Paper 69-28, 19 p.

Brookes, I. A., 1969, Late-glacial marine overlap in western Newfoundland. Canadian Jour. Earth Sci., v. 6, p. 1397-1404.

Buckley, J. T., 1968, Geomorphological map of the Gatineau Park in: Report of Activities, Part B: November 1967 to March 1968: Canada, Geol. Survey Paper 68-1, pt. B, p. 79 .

Christiansen, E. A., 1968a, A thin till in West-Central Saskatchewan, Canada: Canadian Jour. Earth Sci., v. 5, p. 329-336.

1968 b, Pleistocene stratigraphy of the Saskatoon area, Saskatchewan, Canada: Canadian Jour. Earth Sci., v. 5, p. 1167-1173.

Christie, R. L., 1967, Reconnaissance of the surficial geology of northeastern Ellesmere Island, Arctic Archipelago: Canada, Geol. Survey Bull. 138, 50 p.

Churcher, C. S., 1968, Pleistocene ungulates from the Bow River gravels at Cochrane, Alberta: Canadian Jour. Earth Sci., v. 5, p. 1467-1488.

Craig, B. G., 1965a, Glacial Lake McConnell, and the surficial geology of parts of Slave River and Redstone River map-areas, District of Mackenzie: Canada, Geol. Survey Bull. 122, 33 p.

$1965 \mathrm{~b}$, Notes on moraines and radiocarbon dates in northwest Baffin Island, Melville Peninsula and northeast District of Keewatin: Canada, Geol. Survey Paper 65-20, 7 p.

1969, Late-glacial and postglacial history of the Hudson Bay region, in: Earth Science Symposium on Hudson Bay: Canada, Geol. Survey Paper 68-53, p. $63-77$.

Crandell, D. R., Mullineaux, D. R., Miller, R. D., and Rubin, M., 1962, Pyroclastic deposits of Recent age at Mount Rainier, Washington: U.S. Geol. Surv. Prof. Paper 450-D, p. 64-68.

Crary, A. P., 1960, Arctic ice island and ice shelf studies, Pt. II: Arctic, v. 13, p. 32-50

Crary, A. P., Kulp, J. L., and Marshall, E. W., 1955, Evidences of climatic change from ice island studies: Science, v. 122, p. 1171-1173.

Denton, G. H. and Stuiver, Minze, 1966, Neoglacial chronology, northeastern St. Elias Mountains, Canada: Am. Jour. Sci., v. 264, p. 577-599.

- 1967, Late Pleistocene glacial stratigraphy and chronology, northeastern St. Elias Mountains, Yukon Territory, Canada: Geol. Soc. America Bull., v. 78, p. $485-510$.

Dreimanis, A., Terasmae, J., and McKenzie, G. D., 1966, The Port Talbot Interstade of the Wisconsin Glaciation: Canadian Jour. Earth Sci., v. 3, p. 305-325.

Dyck, Willy and Fyles, J. G., 1962, Geological Survey of Canada radiocarbon dates I: Radiocarbon, v. 4, p. 13-26.

1963, Geological Survey of Canada radiocarbon dates II: Radiocarbon, v. 5, p. $39-55$.

Dyck, Willy, Fyles, J. G., and Blake, W., Jr., 1965, Geological Survey of Canada radiocarbon dates IV: Radiocarbon, v. 7, p. 24-46. 
Dyck, Willy, Lowdon, J. A., Fyles, J. G., and Blake, W., Jr., 1966, Geological Survey of Canada radiocarbon dates V: Radiocarbon, v. 8, p. 96-127.

Fernald, A. T., 1962, Radiocarbon dates relating to a widespread volcanic ash deposit, eastern Alaska: U.S. Geol. Survey Prof. Paper 450-B, p. B29-30.

Flint, R. F., 1940, Late Quaternary changes of level in western and southern Newfoundland: Geol. Soc. America Bull., v. 51, p. 1757-1780.

Frankel, L. and Crowl, G. H., 1961, Drowned forests along the eastern coast of Prince Edward Island, Canada: Jour. Geology, v. 69, no. 3, p. 352-357.

Fulton, R. J., 1968, Olympia interglaciation, Purcell trench, British Columbia: Geol. Soc. America Bull., v. 79, p. 1075-1080.

Gadd, N. R., 1964, Moraines in the Appalachian region of Quebec: Geol. Soc. America Bull., v. 75 , p. $1249-1254$.

1968, St. George map-area, New Brunswick (21B, 21G), in: Report of activities, Part A: May to October 1967: Canada, Geol. Survey, Paper 68-1, pt. A, p. 161. 1969, St. Stephen, New Brunswick (21 G/3), in: Report of activities, Part A: April to October 1968: Canada, Geol. Survey, Paper 69-1, pt. A, p. 195-196.

Gadd, N. R. and Karrow, P. F., 1960, Trois-Rivières, Quebec: Canada, Geol. Survey, Map 54-1959.

Gfeller, Chr. and Oeschger, H., 1963, Bern radiocarbon dates III: Radiocarbon, v. 5, p. 305-311.

Goldthwait, R. P., Dreimanis, Aleksis, Forsyth, J. L., Karrow, P. F., and White, G. W., 1965, Pleistocene deposits of the Eric lobe, in: Wright, H. E., Jr. and Frey, D. G., (eds.), The Quaternary of the United States; Princeton Univ. Press, Princeton, New Jersey, p. 85-97.

Grant, D. R., 1968, Recent submergence in Nova Scotia and Prince Edward Island, in: Report of activities, Part A: May to October 1967: Canada, Geol. Survey Paper 68-1, pt. A, p. 162-164.

1969, Recent submergence in Nova Scotia and Prince Edward Island, in: Report of activities, Part A: April to October 1968: Canada, Geol. Survey Paper 69-1, pt. A, p. 199.

Harrison, W. and Lyon, C. J., 1963, Sea-level and crustal movements along the New England-Acadian shore, 4,500-3,000 B.P.: Jour. Geology, v. 71, no. 1, p. 96-108.

Hegg, Otto, 1961, Preliminary report on the palynological field work of 1960 including two radiocarbon datings, in: Jacobsen-McGill Arctic Research Expedition to Axel Heiberg Island, Queen Elizabeth Islands, Prelim. Rept. 1959-1960: Montreal, Ouebec, McGill Univ., p. 201-208.

Henderson, E. P., 1969, Quaternary geology, Kingston (north half), Ontario, in: Report of activities, Part A: April to October 1968: Canada, Geol. Survey, Paper 69-1, pt. A, p. 202-203.

Karrow, P. F., 1963, Pleistocene geology of the Hamilton-Galt area: Ontario Dept. of Mines, Gcol. Rept. no. 16, 68 p.

Karrow, P. F., Clark, J. R., and Terasmae, Jaan, 1961, The age of Lake Iroquois and Lake Ontario: Jour. Geology, v. 69, no. 6, p. 659-667.

Klassen, R. W., 1967, Stratigraphy and chronology of Quaternary deposits of Assiniboine River valley and its tributaries, in: Report of activities, Part B: November 1966 to April 1967: Canada, Geol. Survey Paper 67-1, pt. B, p. 55-60.

Lasalle, Pierre, 1965, Radiocarbon date from the Lake St. John area, Quebec: Science, v. 149 , no. 3686 , p. $860-862$.

1966, Late Quaternary vegetation and glacial history in the St. Lawrence Lowlands, Canada: Lcidse Gcol. Mededel., v. 38, p. 91-128.

Lasalle, Pierre and Rondot, Jehan, 1967, New ${ }^{14} \mathrm{C}$ dates from the Lac St-Jean area, Quebec: Canadian Jour. Earth Sci., v. 4, p. 568-571.

Lee, H. A., 1959, Surficial gcology of southern District of Keewatin and the Keewatin Ice Divide, Northwest Territories: Canada, Geol. Survey Bull. 51, 42 p.

Lerbekmo, J. F., Hanson, L. W., and Campbell, F. A., 1968, Application of particle size distribution to determination of source of a volcanic ash deposit: Internatl. Geol. Cong., XXIII Session; Prague, Czechoslovakia, Proc. sec. 2, "Volcanism and Tectogenesis", v. 2, p. 283-295.

Lerbekmo, J. F. and Campbell, F. A., 1969, Source, distribution, and composition of the White River ash, Yukon Territory: Canadian Jour. Earth Sci., v. 6, p. 109-116.

Lowdon, J. A. and Blake, W., Jr., 1968, Geological Survey of Canada radiocarbon dates. VII: Radiocarbon, v. 10, p. 207-245.

Lowdon, J. A., Fyles, J. G., and Blake, W., Jr., 1967, Geological Survey of Canada radiocarbon dates VI: Radiocarbon, v. 9, p. 156-197. 
Lowdon, J. A., Wilmeth, R., and Blake, W., Jr., 1969, Geological Survey of Canada radiocarbon dates VIII: Radiocarbon, v. 11, p. 22-42.

Lyon, C. J. and Harrison, W., 1960, Rates of submergence of coastal New England and Acadia: Science, v. 132, p. 295-296.

McCallum, K. J. and Wittenberg, J., 1968, University of Saskatchewan radiocarbon dates V: Radiocarbon, v. 10, p. 365-378.

McDonald, B. C., 1968, Deglaciation and differential postglacial rebound in the Appalachian region of northeastern Quebec: Jour. Geology, v. 76, p. 664-677.

1969, Glacial and interglacial stratigraphy, Hudson Bay Lowland, in: Earth Science Symposium on Hudson Bay: Canada, Geol. Survey Paper 68-53, p. 78-99.

Mott, R. J., 1968, A radiocarbon-dated marine algal bed of the Champlain Sea episode near Ottawa, Ontario: Canadian Jour. Earth Sci., v. 5, p. 319-324.

Müller, Fritz, 1963, Radiocarbon dates and notes on the climatic and morphological history, in: Axel Heiberg Island Research Reports: McGill Univ., Prelim. Rept. 1961-1962, p. 169-172.

Müller, Fritz and Barr, William, 1966, Postglacial isostatic movement in northeastern Devon Island, Canadian Arctic Archipelago: Arctic, v. 19, no. 3, p. 263-269.

Olson, E. A. and Broecker, W. S., 1961, Lamont natural radiocarbon measurements VII: Radiocarbon, v. 3, p. 141-175.

Porter, S. C. and Denton, G. H., 1967, Chronology of Neoglaciation in the North American Cordillera: Am. Jour. Sci., v. 265, p. 177-210.

Powers, H. A. and Wilcox, R. E., 1964, Volcanic ash from Mt. Mazama (Crater Lake) and from Glacier Peak: Science, v. 144, p. 1334-1336.

Rampton, V. N., 1969, Pleistocene geology of the Snag-Klutlan area, southwestern Yukon Territory, Canada: unpub. Ph.D. dissertation, Univ. of Minnesota, Minneapolis, Minnesota, $237 \mathrm{p}$.

Rutter, N. W., 1969, Comparison of moraines formed by surging and normal glaciers: Canadian Jour. Earth Sci., v. 6, p. 991-999.

Scholl, D. W. and Stuiver, Minze, 1967, Recent submergence of southern Florida: A comparison with adjacent coasts and other eustatic data: Geol. Soc. America Bull. 4, v. 78 , p. $436-454$.

Stalker, A. M., 1968, Geology of the terraces at Cochrane, Alberta: Canadian Jour. Earth Sci., v. 5, p. 1455-1466.

1969a, Quaternary stratigraphy in southern Alberta. Report II: Sections near Medicine Hat: Canada, Geol. Survey Paper 69-26, 28 p.

1969b, A probable late Pinedale terminal moraine in Castle River Valley, Alberta: Geol. Soc. America Bull, v. 80, p. 2115-2122.

Stuiver, Minze, Borns, H. W., Jr., and Denton, G. H., 1964, Age of a widespread layer of volcanic ash in the southwestern Yukon Territory: Arctic, v. 17, p. 259-261.

Terasmae, Jaan, 1958, Contributions to Canadian palynology: Canada, Geol. Survey Bull. $46,35 \mathrm{p}$.

Terasmae, Jaan and Hughes, O. L., 1960a, A palynological and geological study of Pleistocene deposits in the James Bay Lowlands, Ontario: Canada, Geol. Survey Bull. 62,15 p. p. $1444-1446$.

Tibbetts, T. E. and Kirkpatrick, R. E., 1964, Exploitation of a small peat bog: Canada, Mines Branch, Info. Circ. 160, $48 \mathrm{p}$.

Vernon, Peter and Hughes, O. L., 1966, Surficial geology of Dawson, Larsen Creek, and Nash Greek map-areas, Yukon Territory: Canada, Geol. Survey Bull. 136, 25 p.

Wagner, F. J. E., 1967, Additional radiocarbon dates, Tyrrell Sea area: Maritime Sediments, v. 3, p. 100-104.

Walton, Alan, Trautman, M. A., and Friend, J. P., 1961, Isotopes, Inc. radiocarbon measurements I: Radiocarbon, v. 3, p. 47-59.

Wilcox, R. E., 1965, Volcanic-ash chronology in: Wright, H. E., Jr. and Frey, D. G.. (eds.), The Quaternary of the United States: Princeton Univ. Press, Princeton, New Jersey, p. 807-816. 